\title{
FAULTING OF THE LITHOSPHERE IN THE CENTRAL ASIA AND ACCOMPANYING PROCESSES: TECTONOPHYSICAL APPROACH
}

\section{РАЗЛОМООБРАЗОВАНИЕ В ЛИТОСФЕРЕ ЦЕНТРАЛЬНОЙ АЗИИ И СОПУТСТВУЮЩИЕ ПРОЦЕССЫ: ТЕКТОНОФИЗИЧЕСКИЙ ПОДХОД}

\section{К. Ж. Семинский}

\author{
Институт земной коры СО РАН, Иркутск, Россия
}

Аннотация: В статье представлены сведения об истории, кадровом составе, научной и научно-организационной деятельности лаборатории тектонофизики Института земной коры СО РАН, проводящей в течение 35 лет исследования разломообразования в литосфере. Основная часть статьи посвящена результатам научных работ 2009-2013 гг., в процессе которых сотрудники лаборатории провели полный цикл тектонофизических исследований. Их главными объектами были зонно-блоковая структура литосферы Центральной Азии, разломная тектоника, поля напряжений, механизм формирования и сейсмичность Байкальской рифтовой зоны, эманационная активность разломов земной коры, режим смещений на их фрагментах и другие. Показано, что научные перспективы лаборатории тектонофизики связаны с разработкой комплексных моделей межблоковых деструктивных зон, в основе которых лежат особенности разломного строения, а содержательную часть составляют обусловленные ими закономерности проявления сопутствующих процессов (сейсмическая, эманационная и другие виды активности).

Ключевые слова: тектонофизика, разломы, блоки, поле напряжений, деформации, деструкция, физическое моделирование, Байкальская рифтовая зона, межгорные впадины, сейсмичность, радон. 


\section{1. ВВЕДЕНИЕ}

Изучением процесса разломообразования в литосфере с позиций механики разрушения в Институте земной коры СО РАН занимается лаборатория тектонофизики, которой в 2014 г. исполняется 35 лет. В настоящее время исследования осуществляются в рамках приоритетного направления фундаментальных исследований СО РАН «Катастрофические эндогенные и экзогенные процессы, включая экстремальные изменения космической погоды: проблемы прогноза и снижения уровня негативных последствий» и программы «Тектонофизика современных геодинамических процессов как основа прогноза природных катастроф во внутриконтинентальных условиях». Лаборатория выполняет самостоятельные исследования по проекту НИР «Разломообразование в литосфере Центральной Азии и опасные сопутствующие процессы: тектонофизический подход», финансируемому из госбюджета.

\section{2. ИСТОРИЧЕСКАЯ СПРАВКА}

Решение об организации лаборатории тектонофизики было принято на заседании Ученого совета ИЗК СО РАН в июне 1979 г. Ее первым заведующим был избран д.г.-м.н. С.И. Шерман. Кроме него в составе лаборатории первых лет ее деятельности активно работали К.Г. Леви, С.А. Борняков, В.А. Саньков, Ю.И. Днепровский, В.Ю. Буддо, В.А. Трусков, А.А. Бабичев и другие сотрудники. Им удалось создать тектонофизические основы исследований Байкальской рифтовой зоны, которые, базируясь на геологическом материале о ее строении, отличались существенной новизной и оригинальностью. Этому способствовало начало постановки физических экспериментов по разломообразованию с соблюдением условий подобия. Исследование взаимоотношений численных характеристик параметров разломов в сочетании с физическим и математическим моделированием стало новым направлением работ лаборатории тектонофизики. В 1982-1985 гг. оно было усилено в кадровом отношении за счет прихода в коллектив К.Ж. Семинского, А.Н. Адамовича, А.И. Мирошничеко и А.С. Гладкова. В течение нескольких лет плодотворной деятельности исследования лаборатории вышли на новый уровень: их объектом стали тектонофизические закономерности формирования разломной сети разного масштаба, включая и литосферный. В 1995 г. из лаборатории тектонофизики выделилась группа исследователей, на базе которой была организована лаборатория современной геодинамики во главе с д.Г.-м.н. К.Г. Леви. В свою очередь коллектив лаборатории тектонофизики пополняется новыми сотрудниками, среди которых А.В. Черемных, О.В. Лунина, И.А. Потехина, а впоследствии - А.А. Бобров, Ю.П. Бурзунова,
А.В. Андреев и другие. В 2004 г. д.г.-м.н. К.Ж. Семинский сменил профессора С.И. Шермана на посту заведующего. Создаваемое в течение предыдущих 25 лет основное направление работ лаборатории сохранилось, обогатившись новыми веяниями, вызванными расширением тектонофизических исследований, в том числе в сфере практической геологии. Этому способствует переход в 2013 г. в лабораторию тектонофизики группы сейсмопрогноза (В.В. Ружич, Е.А. Левина, Е.И. Пономарева). В настоящее время коллектив лаборатории сбалансирован по возрасту и опыту проведения тектонофизических исследований. Он состоит из 27 человек, в т.ч. 3 докторов, 8 кандидатов наук, 7 аспирантов и инженерно-технических работников, большую часть которых составляют студенты иркутских вузов (рис. 1).

\section{3. ОСНОВНЫЕ НАУЧНЫЕ НАПРАВЛЕНИЯ}

Лаборатория тектонофизики проводит исследования по четырём основным направлениям:

1) исследование полей напряжений и разломноблоковой структуры литосферы в разных масштабах для выявления тектонофизических закономерностей деструкции на различных иерархических уровнях;

2) исследование механизмов деструкции литосферы в разнотипных динамических режимах методами физического и математического моделирования;

3) разработка теоретических моделей деструкции верхней части литосферы на базе тектонофизического анализа геолого-структурных, картографических и экспериментальных материалов;

4) исследование закономерностей проявления сейсмической и эманационной активности, локализации кимберлитов и рудных месторождений, связанных с разломными зонами земной коры.

\section{4. АППАРАТУРНО-ПРИБОРНАЯ БАЗА И МЕТОДЫ ИССЛЕДОВАНИЙ}

Лаборатория в настоящее время является единственным коллективом в России, проводящим полный комплекс тектонофизических исследований: геологоструктурные работы на базе оригинальной методики спецкартирования разломно-блоковых структур и полей напряжений; геофизические исследования разломных зон верхней коры на основе применения радоновой съемки, электротомографии и георадиолокации; деформометрический и эманационный мониторинг в зонах разломов; физическое моделирование на упругих и упруго-пластичных материалах с использованием полярископа-поляриметра и установки «Разлом»; натурное моделирование режима смещений на разломах с применением различных способов воздействия на породный или ледяной массив (взрывы, домкраты, вибрация и др.) (рис. 2). 


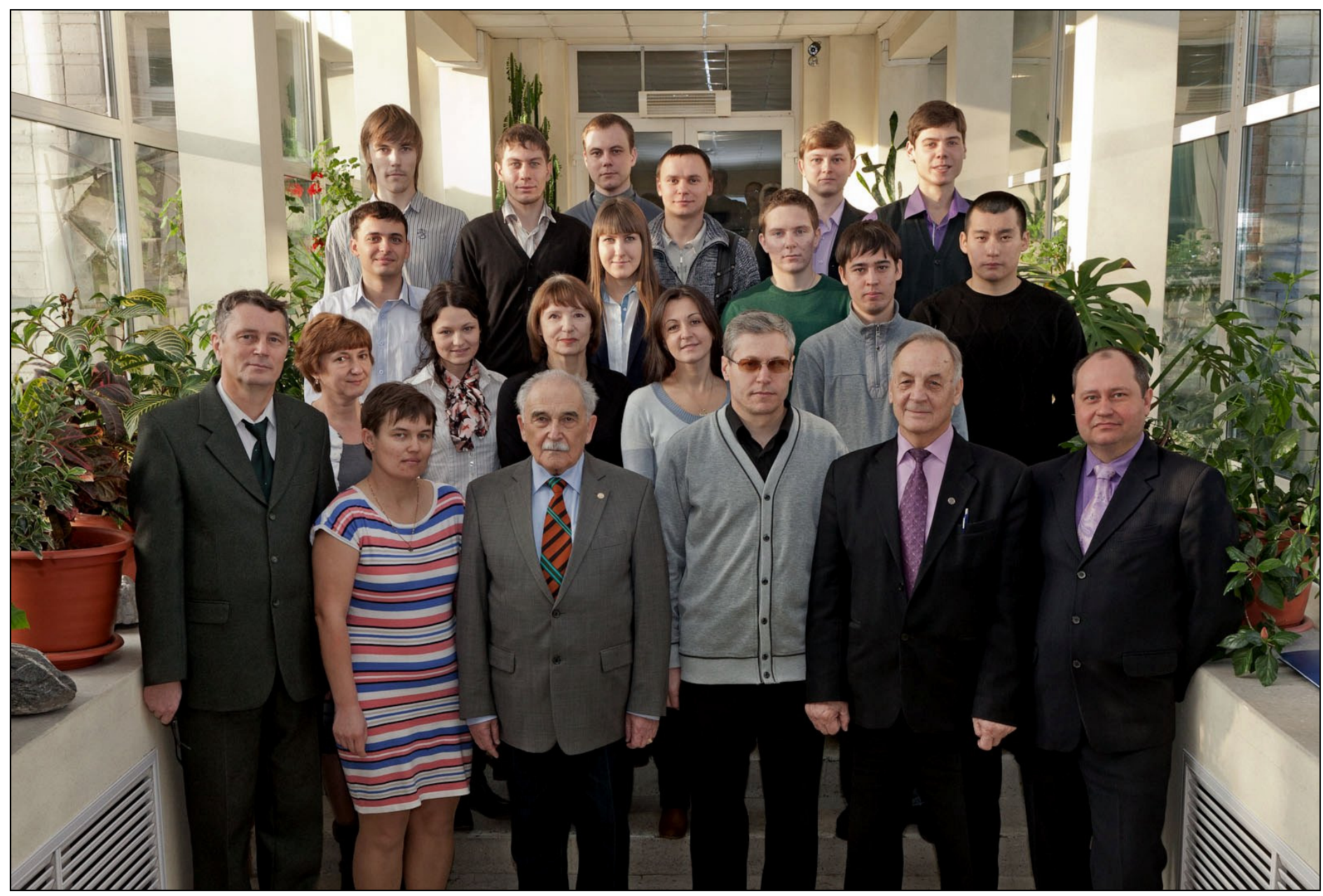

Рис. 1. Коллектив лаборатории тектонофизики (декабрь 2013 г.).

Первый ряд (слева направо): к.г.-м.н. А.С. Гладков, к.г.-м.н. О.В. Лунина, д.г.-м.н. С.И. Шерман - основатель лаборатории, д.г.-м.н. К.Ж. Семинский - зав. лабораторией, д.г.-м.н. В.В. Ружич, к.г.-м.н. А.В. Черемных; второй ряд (слева направо): к.г.-м.н. Е.А. Левина, Ю.П. Бурзунова, И.А. Платонова, к.г.-м.н. И.А. Потехина, И.В. Кузьмин; третий ряд (слева направо): Р.М. Зарипов; А.А. Тарасова, Е.В. Серебряков, А.М. Афонькин; четвертый ряд (слева направо): М.Г. Мельников, А.С. Черемных, А.В. Андреев, к.г.-м.н. А.А. Бобров, А.А. Гладков, А.К. Семинский.

Fig. 1. The staff of the Laboratory of Tectonophysics, December 2013 (left to right).

$1^{\text {st }}$ row - A.S. Gladkov, O.V. Lunina, S.I. Sherman (Founder of the Laboratory), K.Zh. Seminsky (Head of the Laboratory), V.V. Ruzich, A.V. Cheremnykh; $2^{\text {nd }}$ row - E.A. Levina, Yu.P. Burzunova, I.A. Platonova, I.A. Potekhina, I.V. Kuz'min; $3^{\text {rd }}$ row - R.M. Zaripov, A.A. Tarasova, E.V. Serebryakov, A.M. Afon'kin; $4^{\text {th }}$ row - M.G. Melnikov, A.S. Cheremnykh, A.V. Andreev, A.A. Bobrov, A.A. Gladkov, A.K. Seminsky.

\section{5. НАУЧНЫЕ ДОСТИЖЕНИЯ 1979-2008 ГГ.}

Основные научные результаты исследований лаборатории тектонофизики опубликованы в монографических сериях, среди которых наиболее значимыми являются «Геология и сейсмичность зоны БАМ. Неотектоника» (1984), «Разломообразование в литосфере» (Зоны сдвига, 1991; Зоны растяжения, 1992; Зоны сжатия, 1993), «Внутренняя структура континентальных разломных 3он» (Тектонофизический аспект, 2003; Прикладной аспект, 2005). В этих и других моногра- фиях на базе полевых и экспериментальных исследований показано, что деструкция литосферы закономерна для всех иерархических уровней организации разломноблоковой структуры, а установленные параметры деструктивных зон и связывающие их нелинейные уравнения могут быть использованы для объяснения и прогноза геолого-геофизических процессов, контролируемых разломной тектоникой. Прикладную направленность имеет целый ряд разработок, представленных монографиями (Региональные шкалы сейсмической интенсивности, 2003; Методы тектонофизики при ре- 
A

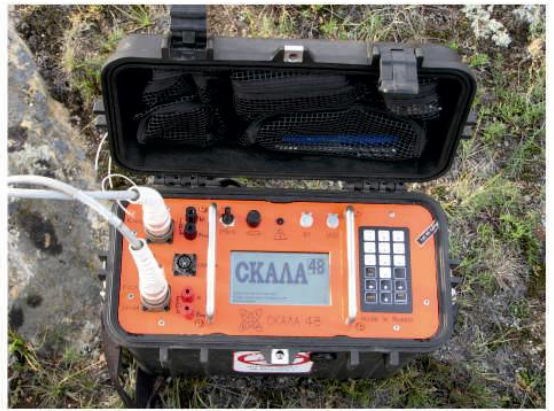

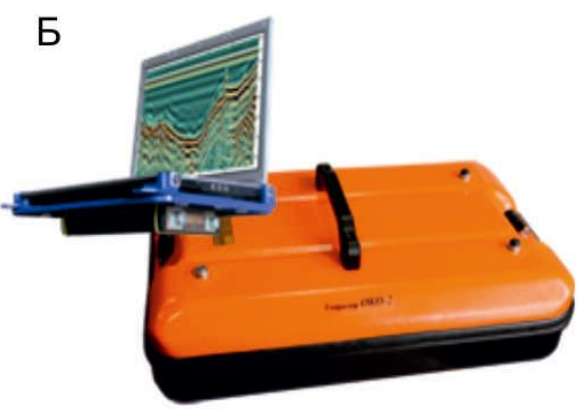

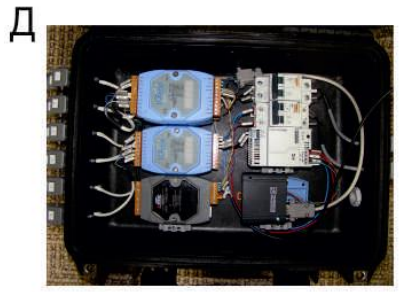

.
B

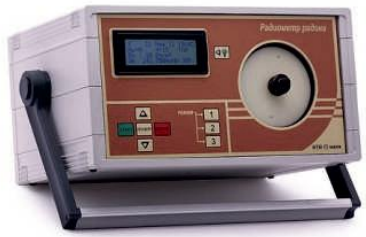

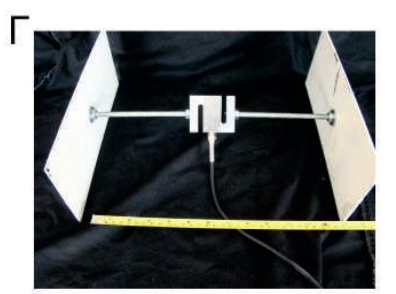

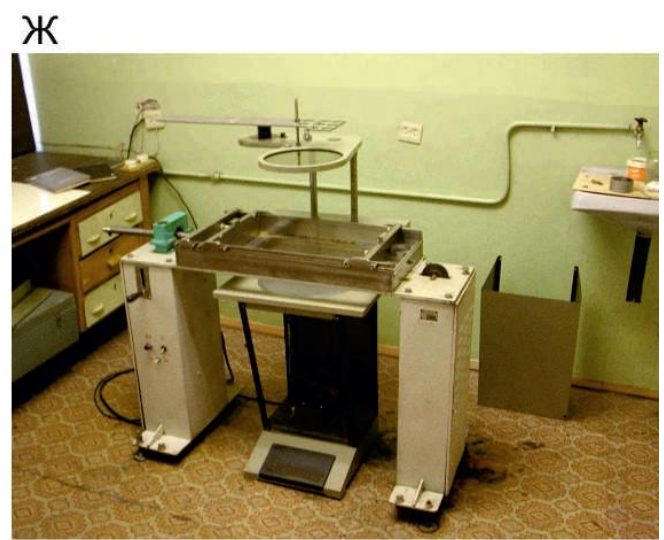

E

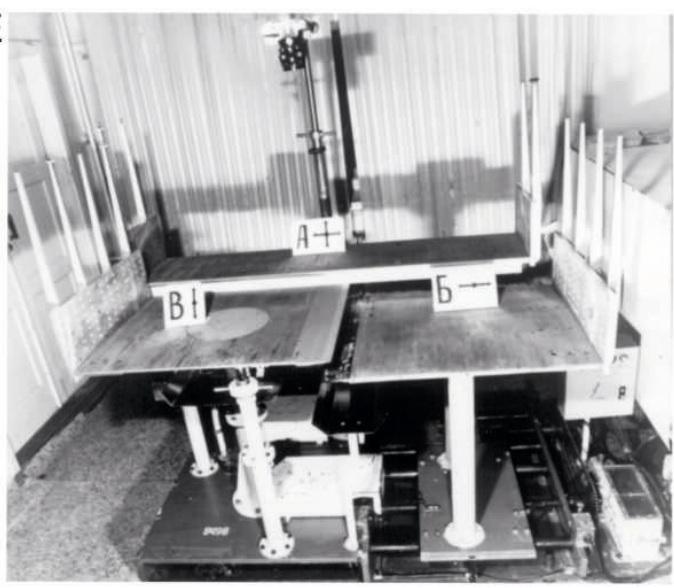


часть из них может быть успешно применена в геологической практике. Следовательно, к настоящему времени рамки тектонофизики существенно расширились, с одной стороны, за счет выхода на решение большой группы прикладных задач, обусловленных спецификой процесса деструкции, а с другой - в связи с необходимостью выявления механизмов формирования деформационных структур литосферного уровня. В следующем, основном, разделе статьи показаны главные научные результаты, полученные в этих областях тектонофизики для Центральной Азии. Этот регион характеризуется высокой активностью современных геодинамических процессов (интенсивное напряженное состояние земной коры, активное разломообразование, сейсмичность, дегазация недр и др.), что способствует выявлению наиболее общих закономерностей деструкции и в то же время выдвигает на первый план решение задач прикладного характера.

\section{6. НАУЧНЫЕ ДОСТИЖЕНИЯ 2009-2013 ГГ.}

Вопросам тектонофизики геодинамических процессов в Центральной Азии посвящено множество научных работ, опубликованных специалистами России и других стран. Ниже представлены главные результаты, полученные по рассматриваемой проблеме в течение последних пяти лет сотрудниками лаборатории тектонофизики Института земной коры СО РАН. Они изложены в кратком иллюстративном виде. Полное описание полученных результатов вместе с обзором достижений предшественников можно найти в публикациях сотрудников лаборатории, помещенных в заключающем статью списке литературы.

\section{1. ТЕОРЕТИЧЕСКИЕ АСПЕКТЫ ТЕКТОНОФИЗИЧЕСКИХ ИССЛЕДОВАНИЙ}

В данном разделе статьи представлены наиболее общие закономерности процесса деструкции, которые были установлены в результате изучения физических моделей и природных объектов, относящихся к литосфере Центральной Азии в целом или представляющим ее крупным сегментам на территории юга Восточной Сибири. Полный цикл тектонофизических работ был проведен с укрупнением масштаба исследований и состоял в следующем: интеграции материалов по напряженному состоянию, закономерностям делимости литосферы и сопутствующей сейсмичности в Центральной и Восточной Азии; проведении аналогичных исследований для юга Восточной Сибири с акцентом на изучение зонно-блоковой структуры, напряженного состояния и активного разломообразования в пределах Байкальской рифтовой зоны (БРЗ) и ее отдельных впадин; физическом моделировании механизма формирования Байкальской рифтовой зоны и ее сегментов.
Закономерности тектонической делимости литосферы Азии были установлены на основе тектонофизического анализа серии схем ее зонно-блоковой структуры [Семинский и др., 2013]. На рис. 3 они представлены для глобального (Центральная и Восточная Азия) и трансрегионального (Прибайкалье и Западное Забайкалье) уровней. Аналогичные построения были проведены в региональном (Центральное Прибайкалье) и локальном (северо-восточная часть Приольхонья в Западном Прибайкалье) масштабах. По результатам количественного анализа системы составленных схем установлены ранги межблоковых подвижных зон, и на основе их сопоставления выделены и статистически охарактеризованы 11 объективно существующих уровней иерархии в зонно-блоковой структуре литосферы Центральной и Восточной Азии. Это позволило установить соответствие делимости литосферы Азии теоретической модели иерархической структурированной среды, состоящей из плит, блоков и ограничивающих их подвижных зон сжатия, сдвига и растяжения. Межблоковые зоны сложной конфигурации отличаются комбинацией режимов деформирования, как это, характерно, например, для Байкальской рифтовой зоны: растяжение - в центре и сдвиги - на юго-западном и северо-восточном флангах. В наиболее общем случае приповерхностную структуру деструктивной (в более крупном масштабе - разломной) зоны образуют протяженные разломы с оперением, совокупные подвижки по которым составляют большую часть смещения по зоне в целом. При меньшей локализованности возрастет роль псевдопластической деформации, осуществляющейся за счет многочисленных подвижек по сравнительно небольшим разрывам. Как следствие, в основу построения схем зонно-блоковой структуры, подобных представленным выше, закладывается выделение деструктивных зон, отличающихся сгущением выраженных в рельефе разломов и эпицентров землетрясений. Объективность этих построений подтвердилась в ходе комплексных исследований Байкальской рифтовой зоны, включающих геолого-структурные методы изучения разрывов и полей напряжений, морфотектонический анализ рельефа (в т.ч. дешифрирование космоснимков), электроразведку методами естественного электрического поля и электропрофилирования, магнитотеллурические зондирования, эманационная съемку, гидрогеологические исследования водопроявлений. Работы проводились совместно со специалистами Института нефтегазовой геологии и геофизики СО РАН, выполнившими весь объем электроразведочных исследований.

Зонно-блоковая структура Байкальской рифтовой зоны отражается в материалах комплексных геологогеофизических исследований [Семинский, Радзиминович, 2011; Семинский, Тугарина, 2011a, 2011б; Черемных, 2009, 2010а, 2010б; Бурзунова, 2011; Семинский, Черемных, 2011; Семинский и др., 2012, 2013; Seminsky, 2013], представленных на примере трансекта Шер- 
A

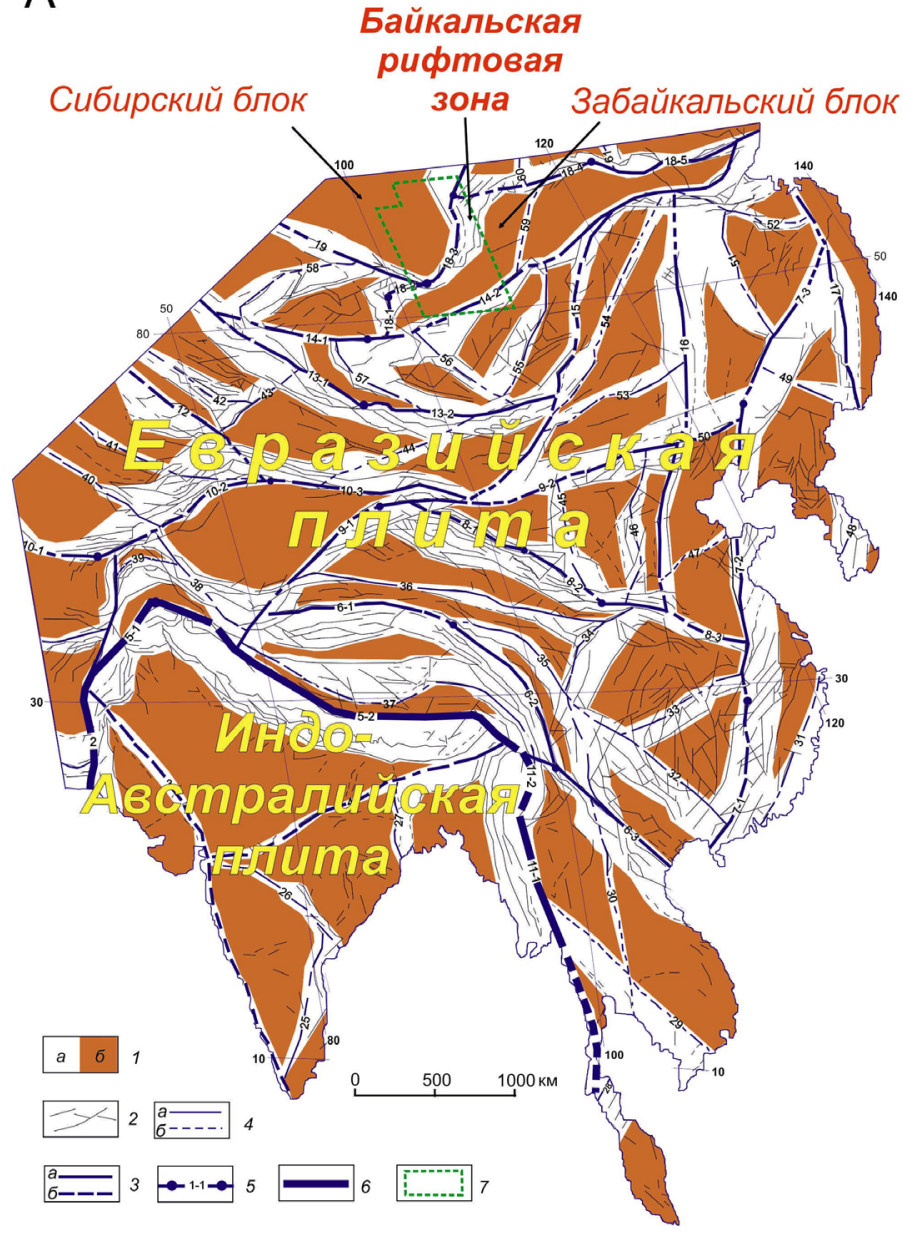

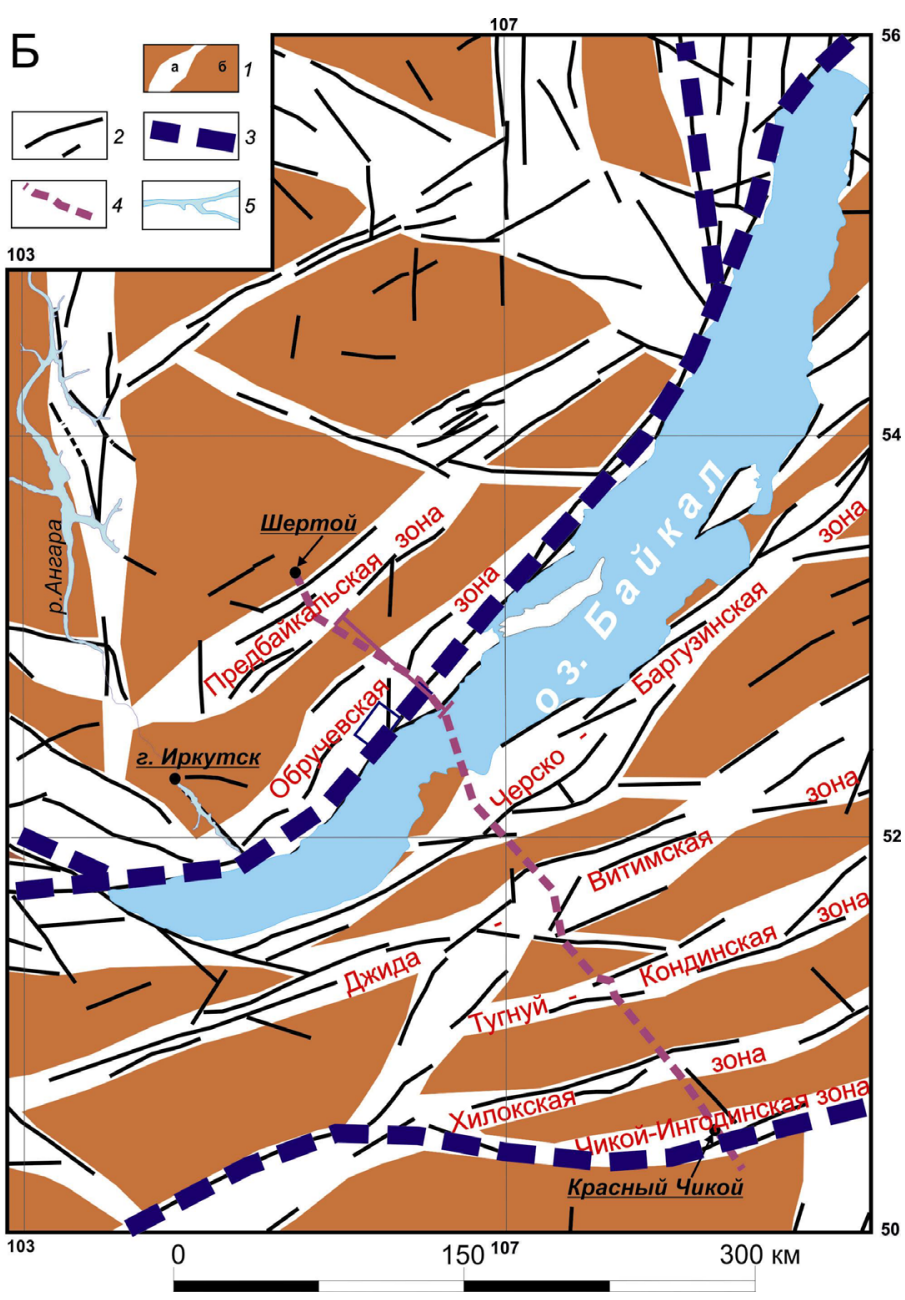

Рис. 3. Схемы зонно-блоковой структуры литосферы на глобальном (А) и трансрегиональном (Б) уровнях иерархии [Семинский и др., 2013].

A - схема для Центральной и Восточной Азии: 1 - межблоковые зоны (а) и блоки (б); 2 - разломы; 3-4 - магистральные сместители межблоковых зон II (3) и III (4) уровней иерархии, совпадающие (а) и не совпадающие (б) с разломами; 5 - индексация межблоковых зон и их сегментов; 6 - магистральные сместители межблоковой зоны I уровня иерархии; 7 - контур рис. 3 , Б. Б - схема для Прибайкалья и Западного Забайкалья: 1 - межблоковые зоны (а) и блоки (б); 2 - разломы, отчетливо выраженные линеаментами рельефа; 3 - границы крупных блоков согласно рис. 3, A; 4 - положение геолого-геофизического трансекта Шертой - Красный Чикой; 5 - гидросеть.

Fig. 3. Schemes of the zonal-block structure of the lithosphere at the global (A) and trans-regional (Б) hierarchic levels [Семинский u дp., 2013].

$A$ - Central and Eastern Asia: 1 - inter-block zones (a) and blocks (б); 2 - faults; 3-4 - major displacement planes of inter-block zones of the $2^{\text {nd }}$ (3) and $3^{\text {rd }}(4)$ hierarchic levels, which coincide (a) and do not coincide (б) with faults; 5 - indexation of inter-block zones and their segments; 6 - major displacement planes of the inter-block zone of the $1^{\text {st }}$ hierarchic level; 7 - contour of Fig. $3, Б$. $Б$ - Pribaikalie and Western Transbaikalie: 1 - inter-block zones (a) and blocks (б); 2 - faults that are clearly manifested in lineaments of the topography; 3 - boundaries of large blocks according to Fig. 3, A; 4 - geological and geophysical transect from Shertoi to Krasny Chikoi; 5 - hydrographic network.

той - Красный Чикой, который полностью пересек ее центральный сегмент, т.е. собственно Байкальский рифт (рис. 3, 4). В приповерхностной части разреза и до глубины 30 км отчетливо проявлено деление земной коры на относительно слабонарушенные блоки, которые контактируют по широким зонам, отличающимся повышенной дислоцированностью и флюидонасыщенностью. Как следствие, в наиболее общем случае они выделяются по сравнению с пространствами блоков понижениями в рельефе, аномалиями усло- вий водообмена, положительными и сложными по форме газовыми аномалиями, а также низкими значениями удельного электрического сопротивления как вблизи поверхности, так и на глубине. В первом приближении блоки имеют плитообразную форму, занимая субгоризонтальное положение в стабильных регионах юга Восточной Сибири (южная часть Сибирской плиты) и субвертикальное - в областях кайнозойской активизации (Байкальский рифт). При детальном рассмотрении межблоковые структуры обычно расши- 

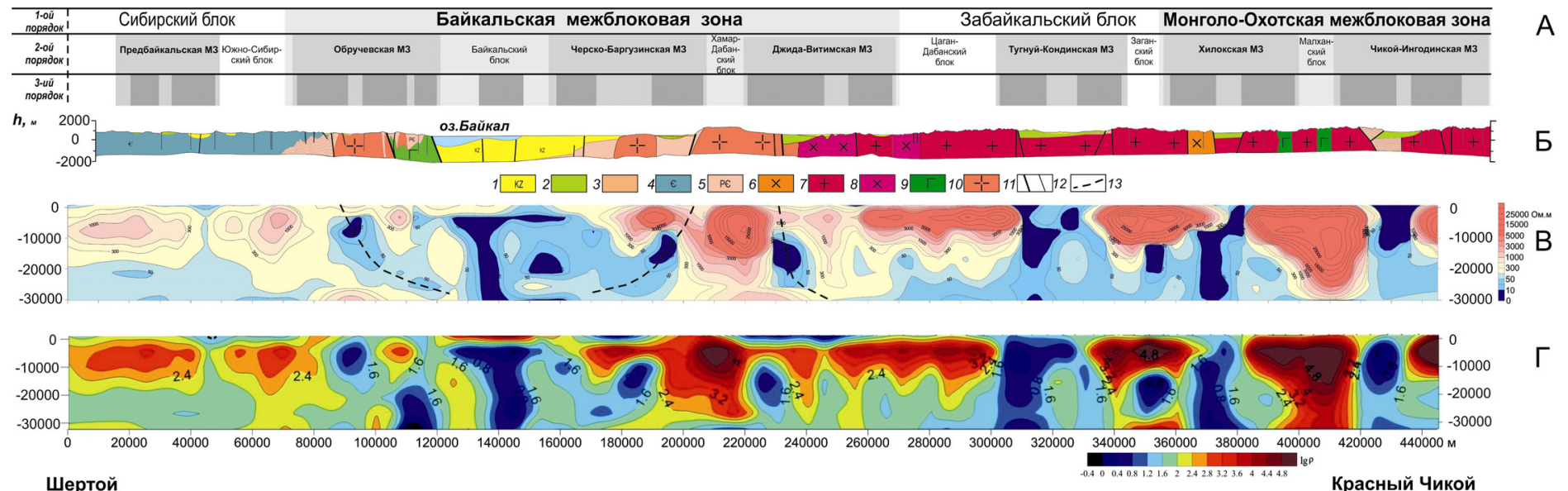

Рис. 4. Проявление иерархии межблоковых зон центральной части БРЗ в глубинном строении земной коры по трансекту Шертой - Красный Чикой [Семинский и др., 2013].

$A$ - иерархия межблоковых зон в пределах трех порядков (границы зон, отмеченные вертикальными полосами с разными оттенками серого цвета, определены по результатам комплексного анализа геолого-геофизических данных). Б - схематичный геолого-структурный разрез (по А.В. Черемных): 1-11 разнотипные вещественные комплексы; 12 - крупные и более мелкие разломы; 13 - оси разломных зон, занимающих периферийное положение в трех разломных системах, составляющих внутреннюю структуру Байкальского рифта. $B-\Gamma-$ геоэлектрические разрезы, построенные по результатам магнитотеллурических зондирований с использованием разных способов представления данных (по Е.В. Поспеевой и В.В. Оленченко). Пунктир - положение на разрезе (рис. 4, В) осей Прихребтовой, Бортовой и Джида-Удинской межблоковых разломных зон.

Fig. 4. Manifestation of the hierarchy of inter-block zones, that are located in the central part of the Baikal rift zone, in the deep structure of the crust along the transect from Shertoi to Krasny Chikoi [Семинский и др., 2013].

A - hierarchy of inter-block zones within three orders (vertical bands coloured in various shades of grey show boundaries of the zones which are determined from results of comprehensive analyses of the available geological and geophysical data). 5 - the schematic geological structural cross-section, according to data provided by A.V. Cheremnykh. 1-11 - real complexes of various types; 12 - large and small faults; 13 - axes of fault zones located at the periphery of the three fault systems comprising the internal structure of the Baikal rift. $B-\Gamma$ - geoelectric profiles reconstructed from results of magnetotelluric surveys, according to data provided by E.V. Pospeeva and V.V. Olenchenko. Dotted lines show positions of axes of the Prikhrebtovaya, Bortovaya and Dzhida-Udinskaya inter-block fault zones shown in the cross-section (see Fig. 4, B).

ряются к поверхности и в тектонически активных зонах 1-го порядка могут превышать поперечные размеры смежных слабонарушенных блоков, соответствующих им по уровню иерархии. Подобная ситуация, характерная для активно развивающегося Байкальского рифта, определяет особенности его строения с позиций представлений о зонно-блоковой делимости литосферы. Так, Байкальская межблоковая зона относится к глобальному уровню иерархии в зонно-блоковой структуре Азии и развивается в режиме растяжения при контактировании Сибирского и Забайкальского блоков литосферы (рис. 4). Вдоль трассы трансекта она имеет ширину примерно 200 км и на трансрегиональном уровне иерархии состоит из Обручевской, Черско-Баргузинской и Джида-Витимской крупнейших разломных зон (систем, согласно зарубежной терминологии). Первые две из них ограничивают с запада и востока опущенный блок Байкальской впадины и, таким образом, составляют главный участок растяжения литосферы. Второй участок представлен ДжидаВитимской разломной системой, отделен от первого высокоподнятым Хамар-Дабанским блоком и в геоморфологическом отношении в пределах трансекта выражен Иволгино-Удинской впадиной. Здесь, вследствие локализации деформации в смежном районе Южно-Байкальской впадины, деструктивный процесс проявляется в меньшей степени, хотя сравнительно высокие индикаторы современной активности - сейсмичность, тепловой поток, газовые эманации и др. отличают Джида-Витимскую зону от территории Забайкальского блока. Каждая из трех трансрегиональных разломных систем имеет ширину примерно 50 км и состоит из региональных межблоковых зон, интенсивно развивающихся в пределах байкальского участка растяжения земной коры. По типу внутреннего строения они представляют зоны крупных разломов: Прихребтового, Приморского и Морского - в Обручевской системе, а также Бортового и Дельтового - в Черско-Баргузинской системе. Прихребтовая и Бортовая разломные зоны, занимая в системах периферийное положение, выполаживаются в направлении оси рифта с глубин примерно 20 км, что придает характерный «чашеобразный» профиль участку наиболее интенсивных деформаций в Прибайкалье (пунктиры на рис. 4). Высокая степень деструкции на фоне общего растяжения коры приводит к насыщению этого участ- 


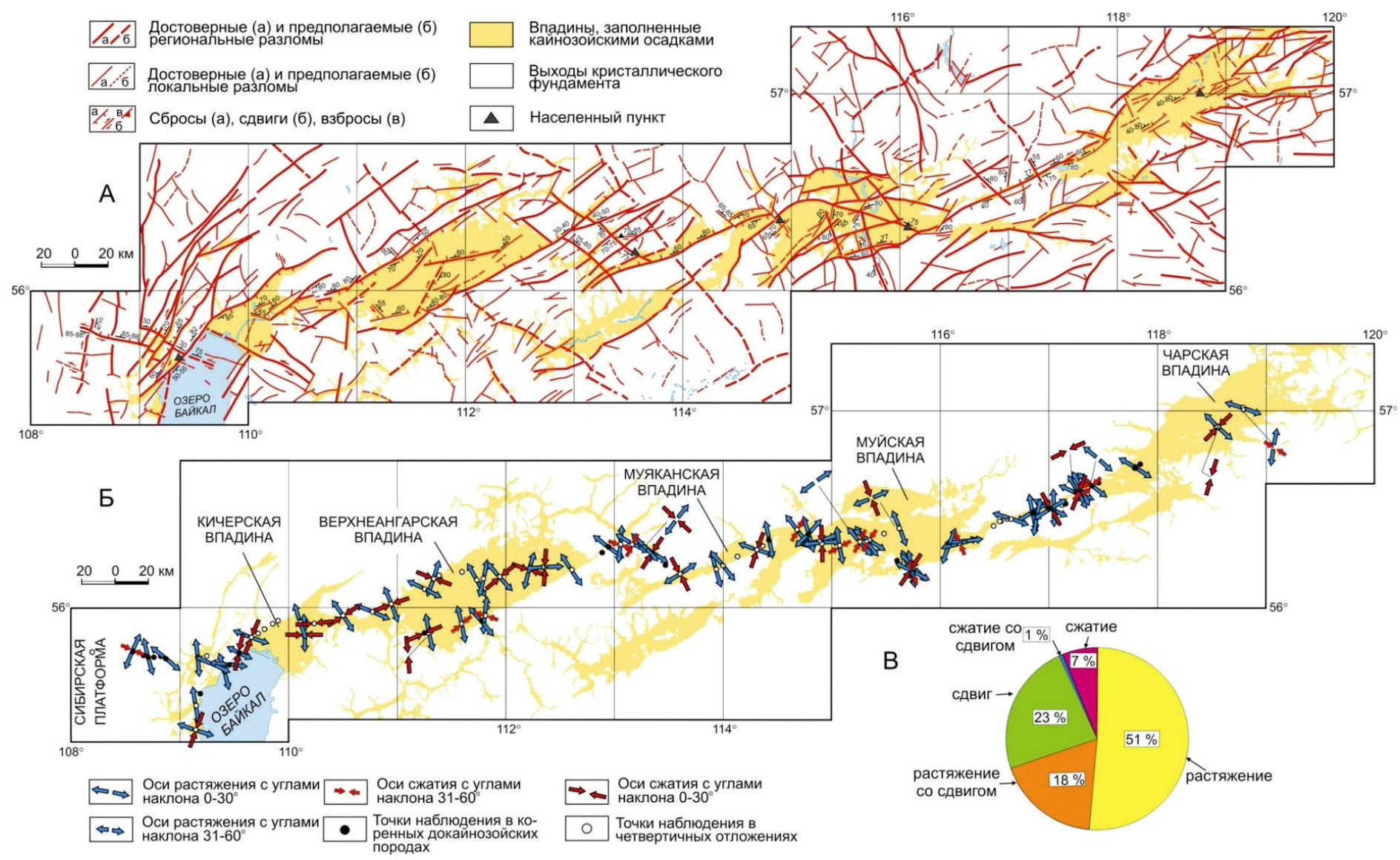

Рис. 5. Поле напряжений земной коры северо-восточного фланга БРЗ по геолого-структурным данным [Лунина и др., 2009].

$A$ - карта разломной тектоники. 5 - схема ориентировок осей главных нормальных напряжений растяжения и сжатия. $B$ - круговая диаграмма, показывающая процентные вклады разных типов напряженного состояния в разрывную структуру района исследований.

Fig. 5. The field of crustal stresses of the north-eastern flank of the Baikal rift zone, according to geological and structural data published in [Lunina et al., 2009].

$A$ - the fault tectonic map. $\overline{-}$ - the scheme showing orientations of main normal stress axes of extension and compression. $B$ - the circle diagram showing contributions (\%) of the state of stresses of various types into the fault pattern of the area under study.

ка флюидами за счет проникновения метеорных вод и глубинных растворов в региональные разломные зоны и, частично, в смежные блоки, которые также принадлежат к внутренней структуре Обручевской и ЧерскоБаргузинской разломных систем. Находящийся между ними блок Байкальской впадины в этом отношении не является исключением, так как нарушен в центре зоной регионального уровня, где вследствие локализации растяжения процесс флюидизации проявлен наиболее интенсивно. Эта зона аномально низких сопротивлений имеет ширину $\approx 7-10$ км и не обнаруживает тенденции к резкому сужению в низах коры, что позволяет считать ее главным каналом для миграции глубинных флюидов к поверхности.

Разломное строение и поля напряжений суходольных впадин рифтовой зоны, являющихся главными элементами структуры крупных разломных зон, исследовались на базе применения геолого-структурных и геоэлектрических методов [Гладков, Лунина, 2010а;
Лунина, Гладков, 2009, 2011; Бержинская и др., 2009; Лунина и др., 2009a, 2009б, 2010а, 2010в, 2011a, 2012a; Lunina et al., 2012]. Для депрессий северо-восточного фланга БР3 (рис. 5), а также Тункинской, Баргузинской, Гусиноозерской, Селенгинской и других впадин охарактеризованы разломно-блоковая структура, глубинное строение, напряженное состояние и сейсмическая активность. Особый акцент был сделан на всестороннем исследовании деформационных структур в заполняющих депрессии кайнозойских осадках. Разработана их классификация на основе специфики происхождения под действием импульсных или криповых тектонических процессов. Доказана эффективность картирования разломных зон геолого-структурными методами для площадей, перекрытых рыхлыми и слабосцементированными отложениями. Дизъюнктивы, выявляемые на поверхности во внутренних частях впадин, согласно материалам электромагнитных зондирований, на глубине отражаются в виде зон низкого 
удельного электрического сопротивления, с которыми ассоциируются изгибы границ осадочных слоев и поверхности кристаллического фундамента. Установлено, что с позднего плиоцена развитие разрывных систем в регионе происходило в условиях превалирующего СЗ-ЮВ растяжения при значительной роли сдвиговых полей напряжений, которые распространены не только на флангах Байкальской рифтовой зоны, но и в других районах Прибайкалья.

Механизм формирования Байкальской рифтовой зоны, не противоречащий представлениям о зонноблоковой структуре литосферы, должен исходить из первичности относительных перемещений Сибирского и Забайкальского блоков литосферы. В основу физического эксперимента были положены известные представления С.И. Шермана, К.Г. Леви и их последователей о Байкальском рифте как структуре присдвигового растяжения. В связи с этим модель из упруго-пластичного материала (влажная глина) располагалась на плоских жестких штампах, один из которых смещался в горизонтальном направлении и на контакте со вторым штампом имел изгиб, имитирующий в первом приближении прибайкальский сегмент краевого шва Сибирской платформы [Семинский, 2009; Семинский, Kогут, 2009]. В серии из 30 экспериментов, один из которых демонстрируется в прикрепленном к статье видеофайле, воссоздавались стабильные условия деформирования, их параметры после пересчета через масштабные коэффициенты в критериях подобия соответствовали природному объекту. Воспроизведенный посредством физического моделирования механизм рифтогенеза позволил объяснить главные пространственно-временные закономерности формирования Байкальской рифтовой зоны: последовательность и двухстадийность эволюционного развития, наличие раздвигового (центральная часть) и сдвиговых (северовосточный и юго-западный фланги) сегментов межплитной границы, морфологию наиболее крупных впадин. В отличие от результатов экспериментальных работ предшественников впервые была достигнута высокая степень подобия в эволюции и взаимном расположении главных межгорных депрессий БРЗ. Следовательно, упруго-пластическая реакция субстрата (1) при реализации левосдвиговых перемещений (2) в области влияния изогнутой в плане инициирующей структурной неоднородности (3) отражает совокупность из трех главных факторов развития природного объекта, реальное сочетание которых может быть достигнуто в сравнительно простом по организации физическом эксперименте. Среди дополнительных факторов на развитие рифтовой зоны безусловное влияние оказывают структурно-вещественные неоднородности литосферы, а также аномальная мантия, активное воздействие которой в период локализации деформации формирует Саяно-Байкальский свод, усиливая вклад обстановки растяжения в развитие современной структуры БРЗ. Выбор главного из обсуждающихся в лите- ратуре энергетических источников возникновения блоковых перемещений - тема будущих исследований, поскольку Индо-Евразийская коллизия вследствие относительной молодости не могла выступать в этом качестве, хотя и способствует прогрессирующей деформации в современную эпоху.

Развитие экспериментальных исследований процесса разломообразования на данном этапе исследований связано с применением законов неравновесной термодинамики, мезомеханики, фрактальной геометрии и теории информации к интерпретации результатов физического моделирования подвижных зон, природными аналогами которых в Монголо-Сибирском регионе являются, например, сдвиговые сегменты БРЗ. Они представляют зоны активных разломов, относящихся к категории открытых систем [Борняков, 2010б; Гуо и др., 2011; Борняков, Семенова, 2011]. Энергия тектонических напряжений, накапливающаяся и перераспределяющаяся в этих зонах под действием различных энергетических источников, расходуется главным образом на медленные криповые и дискретно проявляющиеся быстрые сейсмические диссипативные процессы. Результаты физического моделирования формирования структуры зоны крупного разлома отразили пространственно-временные взаимоотношения разнотипных диссипативных процессов, а также позволили оценить контролирующие их факторы. Установлено, что криповый и сейсмический диссипативные процессы имеют в структурной эволюции разломной зоны конкретную пространственно-временную привязку и действуют в противофазе. В большинстве случаев при максимальной реализации одного из процессов другой характеризуется минимальным проявлением, причем эти моменты совпадают со структурными перестройками - временными границами стадий, этапов или других более мелких эволюционных периодов. Частота повторяемости последних зависит от масштабного уровня деформационного процесса и определяет периодичность активизации криповой и сейсмической диссипации. Полученные закономерности, как и другие результаты представленных исследований, использованы для решения серии прикладных задач, часть из которых представлена в следующем разделе статьи.

\section{2. ПРИКЛАДНЫЕ АСПЕКТЫ ТЕКТОНОФИЗИЧЕСКИХ ИССЛЕДОВАНИЙ}

Главным объектом тектонофизических исследований, востребованных практикой, являются разломы земной коры. Рассматриваемый в структурной геологии как дизъюнктивная граница и/или контролирующая структура, в тектонофизике разлом трактуется как объемное тело, внутреннюю структуру которого, кроме зоны тектонитов магистрального сместителя, составляют все генетически связанные с его формированием пластические и разрывные деформации. Вследствие этого объект может являться сейсмической, 


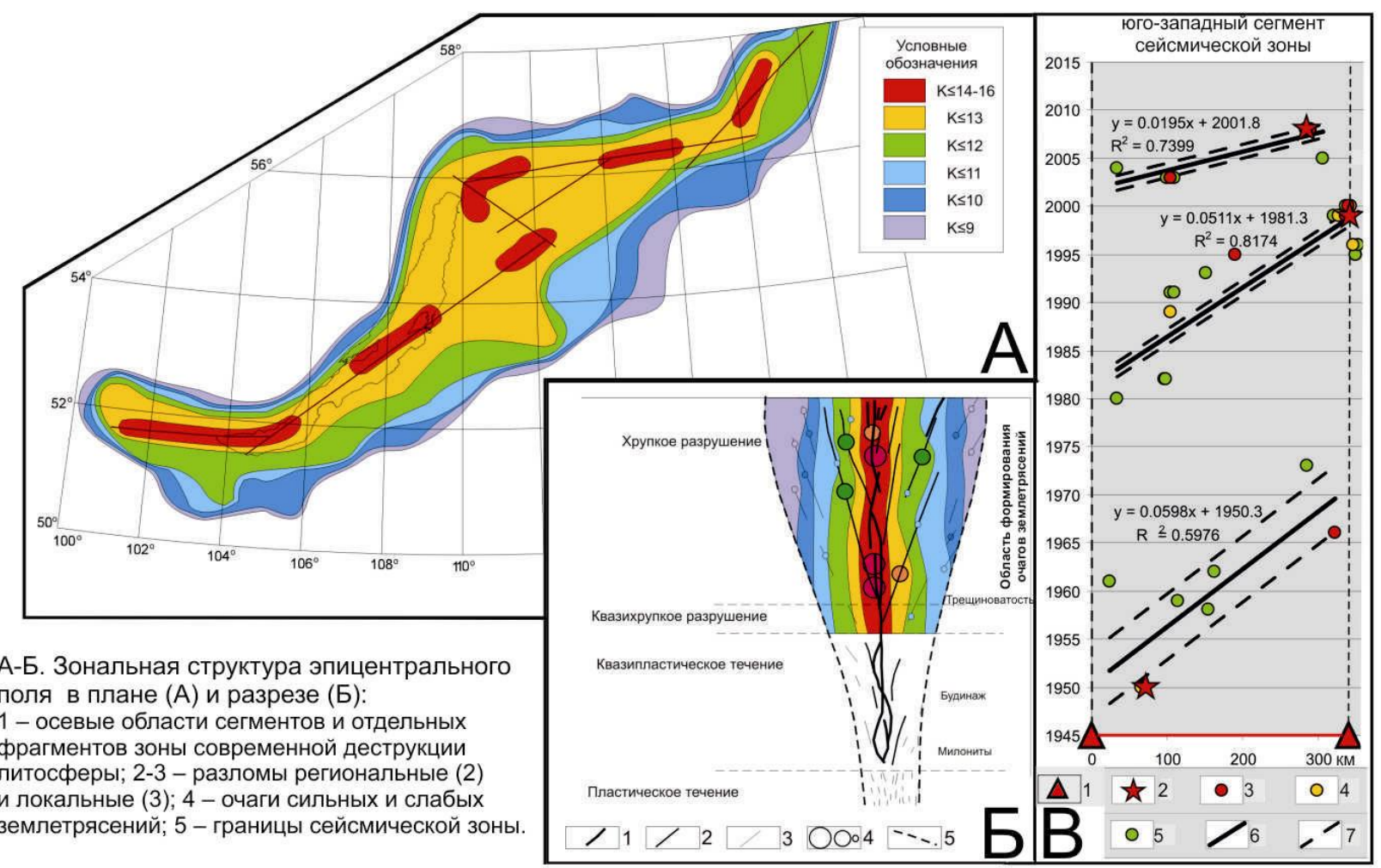

В. Графики временных трендов сейсмических событий (на примрере юго-западного сегмента БСЗ), позволяющие осуществить среднесрочный прогноз локализации землетрясений с $\mathrm{K} \geqslant 12(\mathrm{M} \geqslant 4.4)$ : 1 - западное и восточное окончания

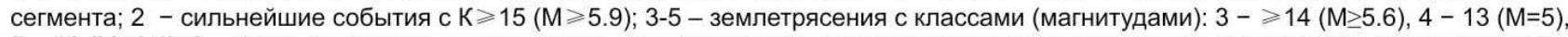
5 - 12 ( $(\mathrm{=}=4.4) ; 6$ - линия регрессии, описывающая пространственно-временные последовательности локализации землетрясений вдоль сегмента; 7 - границы доверительного интервала (90\%).

Рис. 6. Тектонофизическая модель внутриплитной сейсмической зоны (на примере Байкальской рифтовой зоны) [Шерман, 2013].

Fig. 6. The tectonophysical model of an intraplate seismic zone (as exemplified by the Baikal rift zone) [Шерман, 2013].

металлогенической, водоносной или геопатогенной зоной, изучение которых и составляет область всегда актуальных прикладных исследований.

Обобщение результатов предыдущих тектонофизических исследований позволило выделить серию главных закономерностей разломообразования в литосфере. Это, прежде всего, наличие трех стадий в развитии разлома (ранняя, поздняя и полного разрушения), упорядоченная неравномерность нарушенности субстрата и распределения перемещений в зоне его динамического влияния, единый в механическом отношении парагенезис разрывов 2-го порядка, статистические взаимосвязи между ключевыми параметрами разломной зоны. Данные закономерности - основа выявления особенностей разломообразования в регионах с разными режимами развития, а также установления характера протекания в разломных зонах сопутствующих деструкции процессов - сейсмической, эманационной и криповой активности. Такой тектонофизический подход к решению важных в практическом отношении проблем разломообразования с акцентом на анализе сопутствующих опасных процессов являлся главной особенностью исследований, представленных далее.

Сейсмическая активность межблоковых деструктивных и разломных зон является предметом многолетних исследований сотрудников лаборатории тектонофизики, которые проводятся в двух основных направлениях: 1) выявление наиболее общих закономерностей взаимосвязи разломообразования и сейсмической активности в Центральной Азии на базе тектонофизического подхода к анализу сейсмологических данных и 2) экспериментальные исследования на породном массиве и ледяном покрове оз. Байкал процесса предразрушения с выходом на его предвестники и разработку способов управления режимом подвижек на активных разломах.

В рамках первого направления на примере Байкальской рифтовой зоны впервые разработана обобщенная тектонофизическая модель сейсмических зон, развивающихся во внутриконтинентальных условиях Центральной Азии [Леви и др., 2009; Шерман, 2009а, 2009б, 2009в, 20092, 2013; Шерман, Семинский, 2010; Шерман, Злогодухова, 2011; Шерман, Горбунова, 
2011; Шерман и др., 2011, 2012; Горбунова, Шерман, 2012; Ребецкий и др., 2012; Ma Jin et al., 2012; Мельников, 2013]. В реальном времени (месяцы, годы, десятилетия) она может рассматриваться как отдельная, сложно построенная в структурном отношении область литосферы (рис. 6, А, Б). В плане это межблоковая линейно вытянутая зона современной деструкции литосферы (концентратор наиболее сильных землетрясений), представленная густой сетью разноранговых разломов, многие из которых один или несколько раз селективно вовлекались в кратковременный процесс активизации. В вертикальном разрезе сейсмическая зона характеризуется древовидной структурой, ствол и ветви которой представлены разрывами, контролирующими сейсмические события при активизации. Короткопериодная в реальном времени активизация разрывов и пространственно-временные проявления очагов землетрясений в зонах их влияния возбуждаются деформационными волнами, которые в качестве триггера нарушают метастабильное состояние разломноблоковой среды, находящейся под постоянным воздействием регионального поля напряжений. Тектонофизическая модель сейсмической зоны статистически обоснована фактическим материалом, позволившим оценить скорости и периоды деформационных волн, вызывающих активизацию ее различных сегментов и отдельных разломов (рис. 6, В), что, в свою очередь, может служить основанием для определения мест и времени ожидаемых в ближайшее время сейсмических событий. В этих исследованиях хорошо сочетаются теоретические разработки с практическим выходом на вероятностный среднесрочный прогноз землетрясений.

Исследования в рамках второго научного направления были связаны с совершенствованием физических основ среднесрочного и долгосрочного прогноза землетрясений в пределах Байкальской рифтовой зоны и смежных территорий [Ружич, 2009; Ружич и др., 2009a, 2009б; Востриков и др., 2009; Имаев и др., 2009; Шилько и др., 2009; Psakhie et al., 2009, 2010; Борняков, 2010; Борняков, Встовский, 2010; Псахье и др., 2010; Рассказов и др., 2010; Radziminovich et al., 2010; Vstovsky, Bornyakov, 2010; Добрецов и др., 2011; Черных и др., 2011; Деструкция..., 2012; Астафуров и дp., 2013; Chernykh et al., 2013]. Они проводились при сотрудничестве с региональными органами МЧС, куда ежеквартально отправлялись оперативные сводки об изменениях сейсмической обстановки в регионе. Опыт этих работ показал, что недостатки среднесрочного прогноза в нашей стране и за рубежом обусловлены дефицитом данных, прежде всего, о процессах подготовки очагов землетрясений в глубинных сегментах зон разломов. Для продвижения в совершенствовании среднесрочного прогноза нужны дополнительные геолого-геофизические и детальные сейсмологические исследования с применением новых видов аппаратуры, что требует существенных капиталовложений.

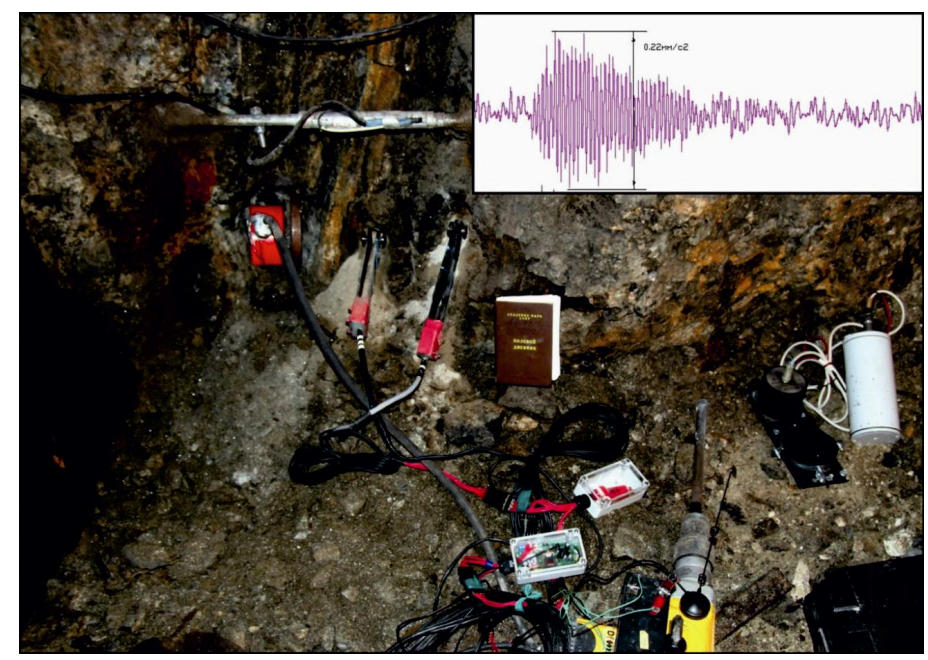

Рис. 7. Проведение испытаний в штольне «Талая», расположенной в зоне Главного Саянского разлома, для изучения последствий отклика залеченной трещины в породном массиве на воздействия домкратом, вибрациями и ударами (материалы В.В. Ружича).

На врезке показан вид сейсмической записи одного из инициированных импульсов при мгновенном сбросе давления в домкрате.

Fig. 7. Tests in the Talaya mine gallery located in the Main Sayan fault zone. A cured fracture in the natural massif was subject to impacts of a hoisting jack, vibrations and shocks, and its responses were studied (the information is provided by V.V. Ruzhich).

The insert shows a seismic record of an initiated impulse in case of instantaneous pressure drop when the jack was used.

Кроме того, среднесрочный прогноз всегда будет только вероятностным, и он не спасает от ущерба при сильных землетрясениях. Развивающийся в лаборатории новый подход к решению проблем обеспечения сейсмобезопасности связан с разработкой способов управления деформациями в зонах разломов на стадии подготовки очагов землетрясений с применением механических воздействий посредством взрывов, ударов копром, мощных домкратов, закачек водных растворов и вибровоздействий (рис. 7). Кроме того, в течение многих лет осуществлялись инструментальные наблюдения за ходом динамических явлений в ледовом покрове оз. Байкал, разрушение которого протекает по ряду признаков подобно сейсмотектоническому процессу в земной коре.

В качестве главного вывода, полученного на основе интерпретации собранных данных, установлено, что, применяя различные режимы комплексных техногенных воздействий на сегменты разломов в пределах высоконапряженных породных массивов, можно инициировать динамические явления или предупредить их возникновение за счет перераспределения волновой энергии в тепловую, при регулируемом изменении 


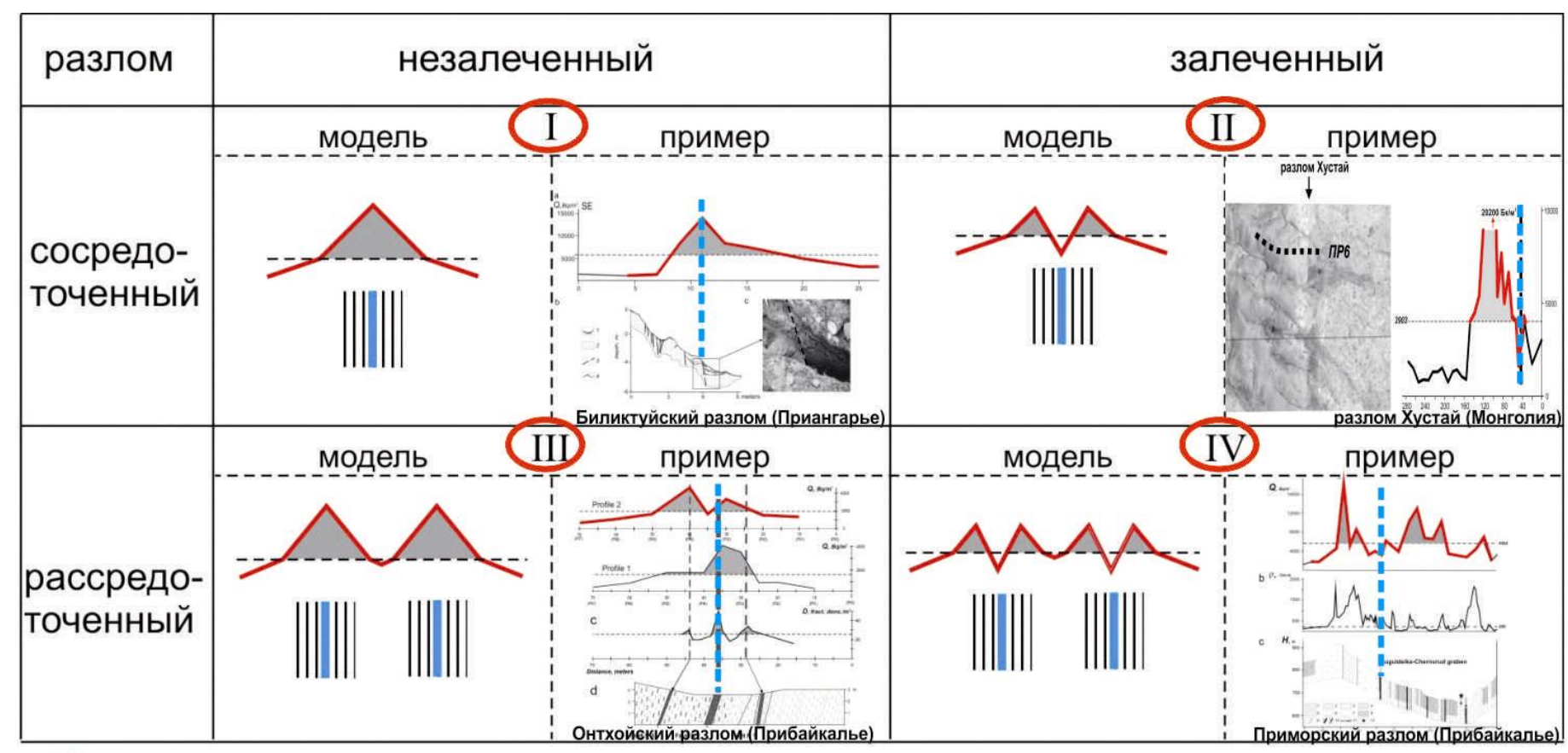

- график объемной активности почвенного радона (Q) вкрест разлома (пунктир - уровень среднего значения)

зона тектонитов

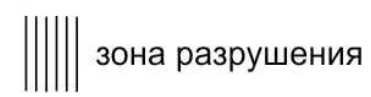

поле аномальных значений параметра Q

Рис. 8. Типы аномалий радона (I-IV), формирующихся над разломами, которые отличаются по структуре (сосредоточенные или рассредоточенные) и/или наличию заполнителя (незалеченные или залеченные) [Radon..., 2012].

Fig. 8. Types of radon anomalies (I-IV) that form above faults. Such anomalies differ in structure (they may be concentrated or non-concentrated) and / or presence of infilling material (cured or non-cured [Radon..., 2012].

скорости скольжения крыльев разломов. В практическом плане разработка технологии в рамках реализации данного подхода может уже в ближайшие годы способствовать снижению риска опасных динамических явлений в районах расположения уязвимых промышленных сооружений, а также при проходке подземных горных выработок на больших глубинах - 1-4 км. При дальнейшем совершенствовании способов безопасной разгрузки очагов горных ударов открываются перспективы разработки аналогичных подходов по отношению к готовящимся коровым землетрясениям. Разработка этих технологий намного сложнее, но она становится все более реальной.

Эманационная активность разломных зон изучалась в ходе многолетних исследований на юге Восточной Сибири и в Монголии [Семинский, Бобров, 2009a, 2009б; Семинский и др., 2012a; Radon..., 2012; Seminsky, Demberel, 2013]. Интерпретация полученных данных с позиций выявленных ранее закономерностей разломообразования позволила установить, что интенсивность выхода радона через разломные зоны земной коры характеризуется периодической изменчивостью во времени и резко неравномерным распределением в пространстве. Форма и размер аномалии почвенного радона зависят от специфики внутреннего строения и геодинамической активности разломной зоны. Определяющее влияние этих факторов осложняется наличием в разрезе тонкодисперсных продуктов эрозионных процессов и выветривания, препятствующих выходу газа в атмосферу. По форме поперечного профиля выделено четыре типа приразломных аномалий радона (I-IV), отражающих структурные ситуации, которые образуются при различных сочетаниях двух признаков (рис. 8): разновидность разлома (сосредоточенный - на ранней стадии или рассредоточенный - на поздних стадиях развития) и наличие (или отсутствие) в зоне его влияния тонкодисперсного заполнителя. Поперечные размеры эманационной аномалии несколько превышают ширину разломной зоны, включающую все разрывы, связанные с формированием главного сместителя, который в большинстве случаев из-за низкой проницаемости тектонитов маркируется минимумом концентрации почвенного радона. Контрастность эманационных аномалий, которая оценивалась при помощи относительного показателя $K_{Q}=Q_{\max }$ / $Q_{\min }$ (где $Q_{\max }$ - максимальное значение параметра $Q$, а $Q_{\min }-$ минимальное значение параметра $Q$ в породах за границей зоны разлома), тяготеет у выборки из десятков изученных дизъюнктивов к определенным уровням данного параметра. Это позволило выделить 
пять групп разломных зон: с низкой $\left(K_{Q} \leq 2\right)$, средней $\left(2<K_{Q} \leq 3\right)$, повышенной $\left(3<K_{Q} \leq 5\right)$, высокой $\left(5<K_{Q} \leq 10\right)$ и сверхвысокой $\left(K_{Q}>10\right)$ радоновой активностью. Зоны влияния разломов двух последних групп представляют опасность в плане строительства и эксплуатации зданий, в которых длительное время находятся или живут люди. Установленные закономерности являются основой для создания в будущем новой технологии оценки радоноопасности территорий, в которой, кроме наличия радиоактивных пород, значимым фактором является существование в земной коре зон активных разломов.

Проблема контроля разломными зонами алмазоносных кимберлитов на Сибирской платформе имеет двойное значение для практики. Во-первых, это выделение перспективных площадей для поисков новых трубок и, во-вторых, прогноз наиболее нарушенных участков горных выработок (карьеров и шахт) с целью обеспечения безопасности горно-эксплуатационных работ на разрабатываемых месторождениях алмаза [Гладков и др., 2010б; Константинов, Гладков, 2009]. Работы в рамках данной проблемы охватили полный цикл тектонофизических исследований, в результате которого были в первую очередь выявлены главные закономерности строения разрывных сетей в различных структурных этажах Сибирской платформы как единой длительно развивающейся тектонической единицы. Тектонофизическими методами установлена взаимосвязь периодов формирования кимберлитовых тел с этапами становления и активизации разрывной структуры платформенного чехла. Впервые показано, что определяющую роль в структурном контроле кимберлитового магматизма на Сибирской платформе играют разломные зоны ортогональной сети, активизировавшиеся в режиме знакопеременных движений на разных этапах ее развития в палеозое и мезозое. Положение отдельных кимберлитовых полей в пределах субширотных и субмеридиональных разломных зон контролируется системами разрывов 2-го и более высоких порядков, которые заметно отличаются по строению и согласуются с типами полей напряжений, действовавшими в различные эпохи внедрения кимберлитов. Отдельные магматические трубки, как правило, приурочены к структурам растяжения, возникающим на разных этапах тектогенеза в результате взаимодействия субширотных и/или субмеридиональных нарушений на участках окончаний или в узлах пересечений (рис. 9). Установленные закономерности представляют основу выделения на Сибирской платформе новых перспективных площадей, тогда как схемы разломов, составленные для эксплуатируемых месторождений алмаза, являются базовым материалом для разработки безопасной тактики горнорудного производства.

Активные разломы земной коры являются объектом исследований, представляющим особую значимость для практики в связи с нуждами строительства зданий и сооружений, прогнозом сильных землетрясений, а также опасных инженерно-геологических процессов, интенсивно протекающих в зонах их динамического влияния. Кроме картирования этих структур на местности, особое значение на современном этапе имеет создание геоинформационных систем, включающих базы данных по активным разломам какого-либо региона и программное обеспечение, позволяющее в удобной и доступной форме обрабатывать имеющиеся материалы. Сотрудниками лаборатории тектонофизики [Лунина, 2010; Лунина и др., 2010б, 2011б, 2012б; Андреев, Лунина, 2012; Гладков и др., 2012, 2013] для территории юга Восточной Сибири (50-57 ${ }^{\circ}$ с. ш. и $100-114^{\circ}$ в. д.) созданы карта и база данных активных (в неоген-четвертичное время) разломов с сопутствующей информацией об опасных геологических эффектах, сопровождавших умеренные и сильные землетрясения (разрывы, разжижение, воронки-провалы, склоновые движения). База данных позволяет путем электронных запросов классифицировать разломные сегменты по времени последней активизации, кинематике, степени активности и другим характеристикам. Так, на основе созданной базы данных в среде ГИС MapInfo составлена карта активных разломов юга Восточной Сибири, способных генерировать землетрясения с магнитудой 5.5 и выше (рис. 10). Возможность инициирования таких сейсмических событий доказана на основе комплексного тектонофизического анализа связи инструментальных и исторических землетрясений с разломами, палеосейсмогеологических признаков активности и представлений о принадлежности дизъюнктива к зоне возникновения очагов землетрясений, выделенных предшественниками. На карте сейсмоактивные структуры разделены по возрасту последней активизации. Анализ базы данных показал, что главными источниками землетрясений с $\mathrm{M}>5.5$ на юге Восточной Сибири являются северо-восточные сбросы и субширотные разрывы с левосторонней компонентой горизонтального смещения. Это согласуется с приуроченностью к тем же направлениям разрывов тектонических деформаций в рыхлых и слабосцементированных осадках плиоцен-четвертичного возраста и свидетельствует о их бо́льшей активности по сравнению с дизъюнктивами других ориентировок. Карта, представленная на рис. 10, а также другие результаты использования созданной базы данных являются основой решения многих прикладных задач, связанных с прогнозированием опасных природных процессов, сопутствующих деструкции земной коры.

\section{7. ПЕРСПЕКТИВЫ РАЗВИТИЯ И НАУЧНО- ОРГАНИЗАЦИОННАЯ ДЕЯТЕЛЬНОСТЬ ЛАБОРАТОРИИ}

Исследования процесса деструкции литосферы Центральной Азии на разных уровнях иерархии, про- 


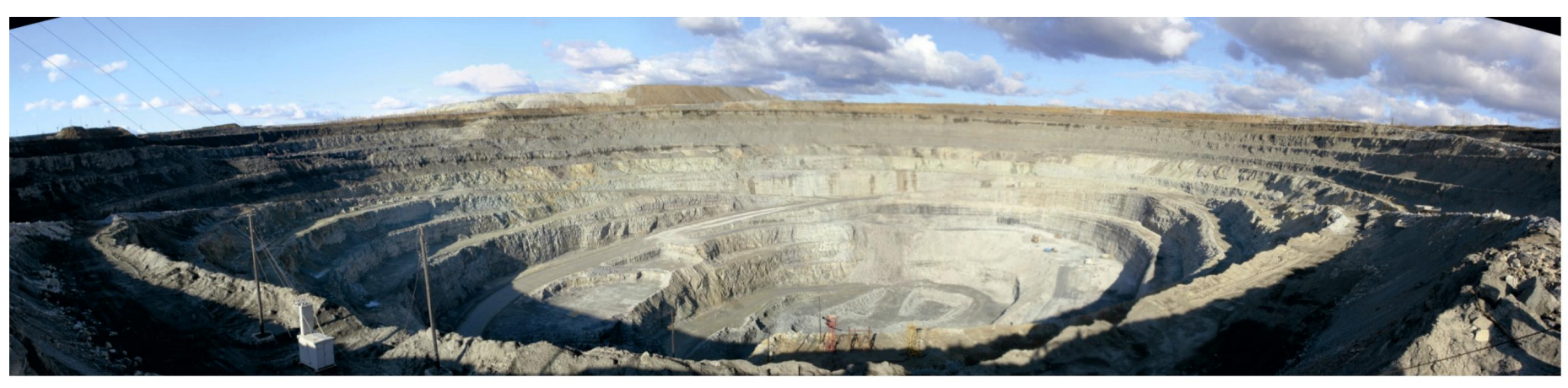

A

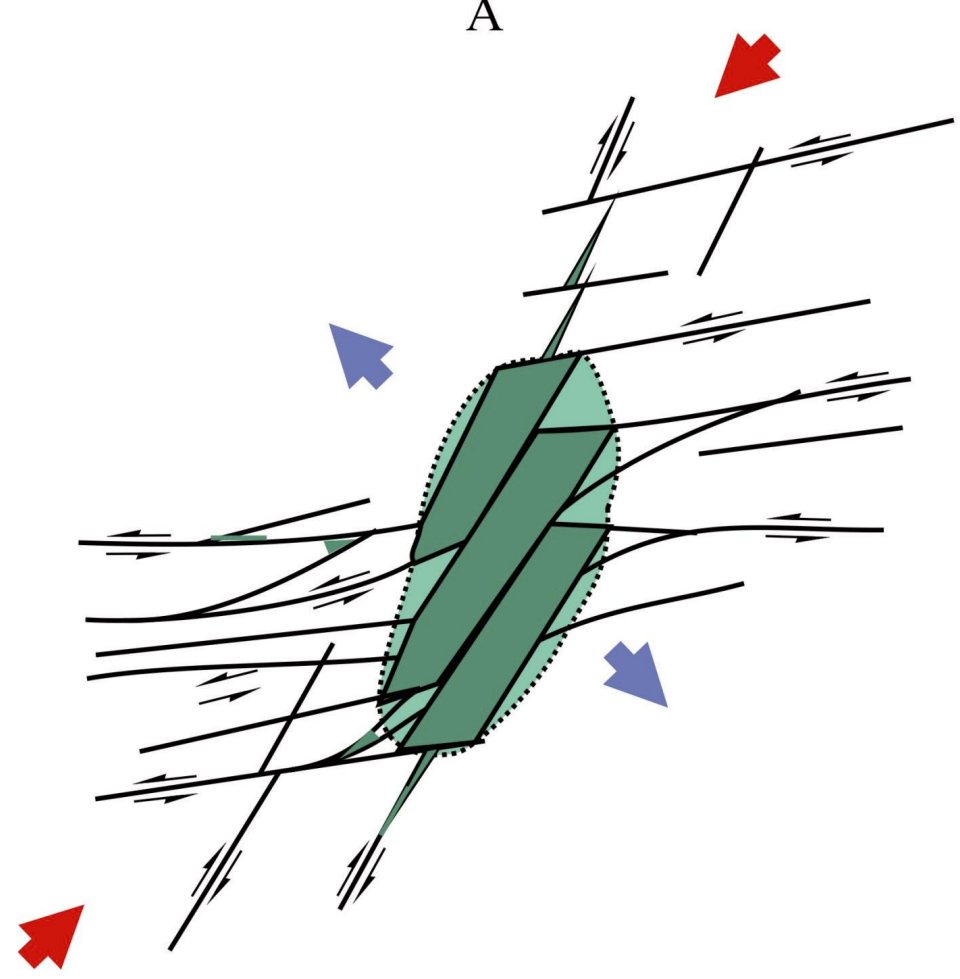

Б

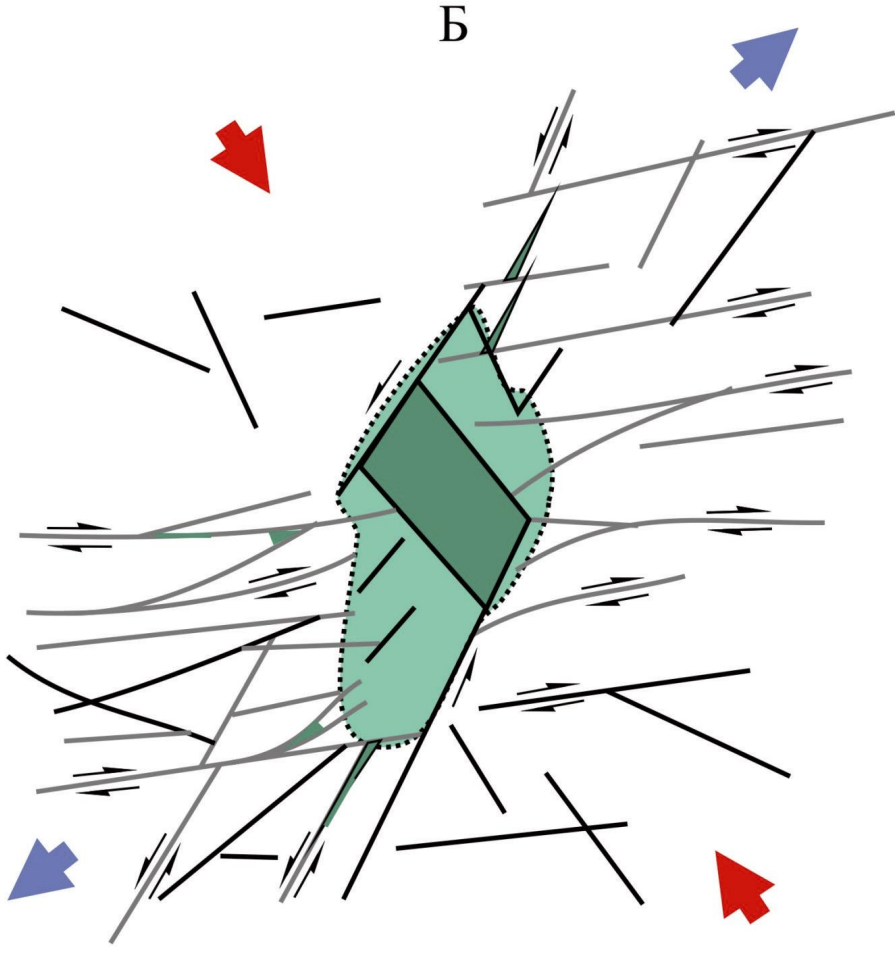

Рис. 9. Структурная модель формирования кимберлитового тела трубки «Нюрбинская» (вверху - фото карьера в 2008 г.) в узле взаимодействия Широтного и Диагонального разломов на первом (А) и втором (Б) этапах проявления знакопеременных сдвиговых движений [Гладков и др., 2010б].

A - первый этап. Темно-зеленым цветом показана серия структур типа пулл-апарт, возникающих в результате раскрытия разрывов Диагонального разлома на участке взаимодействия с разрывами Широтного разлома. Оконтуренное точками светло-зеленое поле отвечает предполагаемой форме трубки в конце первого этапа. Б - второй этап. Оконтуренное точками светло-зеленое поле отражает конечную форму трубки, деформированной в результате левосдвиговых смещений по разрывам Диагонального разлома. Темно-зеленым цветом показана структура пулл-апарт, с которой может быть связано внедрение последних фаз кимберлитового расплава. Большими стрелками обозначено направление действия сил сжатия (красные) и растяжения (синие). Сплошные линии соответствуют разрывным нарушениям в зонах и узле Широтного и Диагонального разломов. Черные стрелки показывают направления сдвиговых смещений на обоих этапах деформирования.

Fig. 9. The structural model of formation of the kimberlitic body of the Nyurbinskaya pipe (top - a photo of the quarry in 2008) at the junction of the Lateral and Diagonal faults at Stage $1(A)$ and Stage $2(D)$ when alternating-sign shear movements were manifested [Gladkov et al., 2010b].

$A$ - Stage 1. Series of pull-apart structure are shown in dark green; such structures results from opening of fractures that comprise the Diagonal fault at the junction with fractures comprising the Lateral fault. The assumed shape of the pipe at the end of Stage 1 is shown as a light green field contoured by dots. 5 - Stage 2 . The light green field contoured by dots shows the final shape of the pipe after it was deformed by left-lateral displacement along the fractures comprising the Diagonal fault. The pull-apart structure is shown in dark green; intrusions of the late phases of kimberlitic melt may be associated with the given structure. Big red arrows show directions of compression; big blue arrows show directions of extension. Solid lines show faults in the zones and the junction of the Lateral and Diagonal faults. Black arrows show directions of shear displacements at both stages of deformation. 

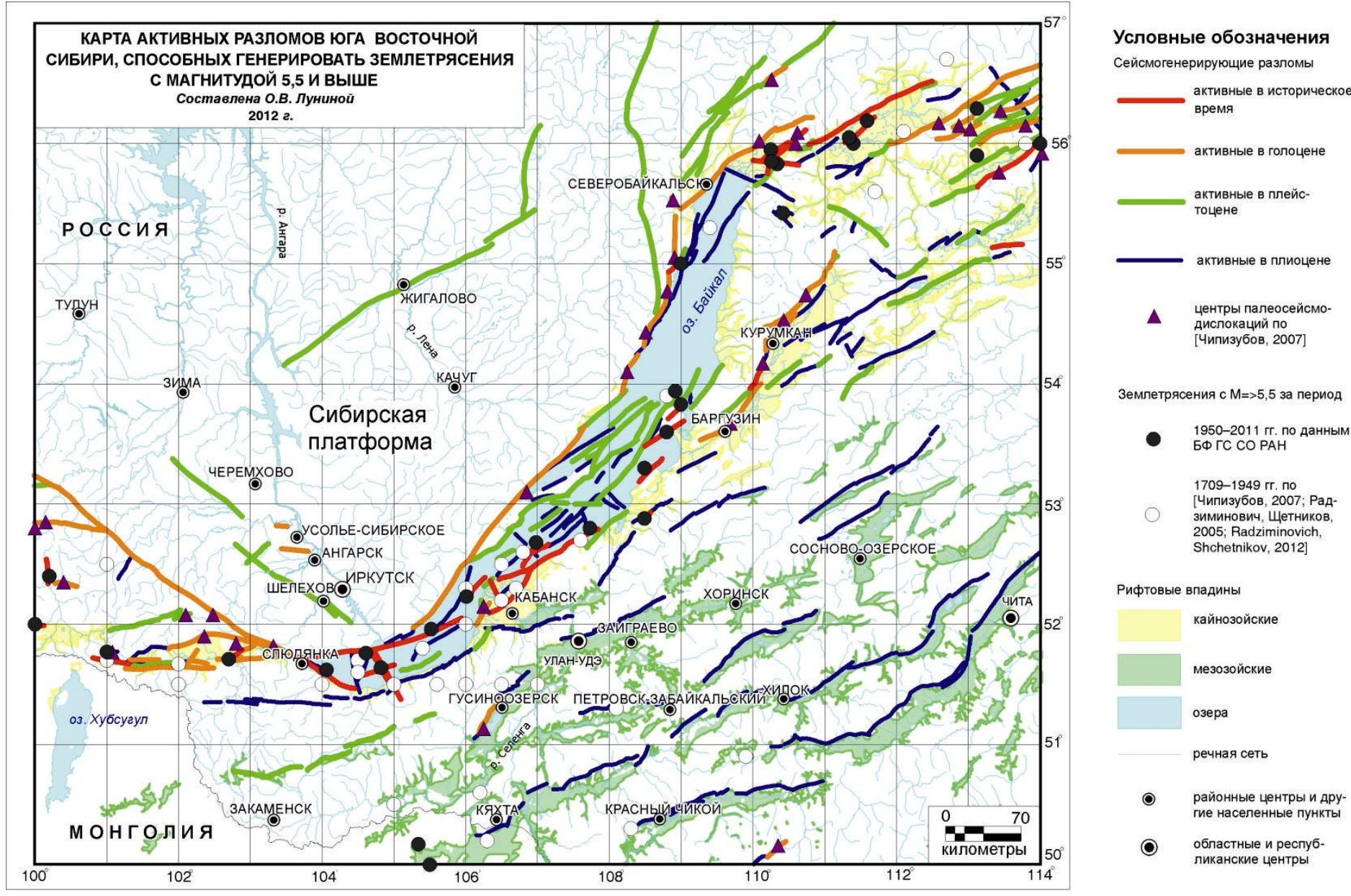

Землетрясения с $\mathrm{M}=>5,5$ за период

- 1950-2011 ге. по данным БФ ГС СО РАН

1709-1949 гr. по [Чипизубов, 2007; Рад зиминович, Щетников, Shchetnikov, 2012]

Рифтовые впадины

кайнозойские

мезозойские

озера

речная сеть

гие населенные пункты

(-) областные и респубойанские центры

Рис. 10. Карта активных разломов юга Восточной Сибири, способных генерировать землетрясения с магнитудой 5.5 и выше [Лунина и др., 2012б].

Fig. 10. The map of active faults of the southern regions of East Siberia. Such faults can generate earthquakes of M $\geq 5.5$ and stronger seismic events [Lunina et al., 2012b].

веденные сотрудниками лаборатории тектонофизики в 2009-2013 гг., позволили получить результаты, имеющие теоретическое и практическое значение. Установлены главные закономерности разломного строения, напряженного состояния, современной активности (сейсмической и радоновой) и механизма формирования Байкальского рифта - главной активной межблоковой зоны на юге Восточной Сибири. Разработана тектонофизическая модель Байкальской сейсмической зоны. Установлены количественные характеристики и специфика внутреннего строения радоновой аномалии, обусловленной формированием Байкальского рифта. Проведена систематизация геолого-геофизической информации, и создана база данных по активным разломам, композитным и индивидуальным сейсмогенным источникам, а также косейсмическим эффектам в Байкальской рифтовой зоне и смежных регионах.

Комплексный анализ этих результатов показал, что реальная картина тектонической делимости в Центральной Азии соответствует тектонофизическим представлениям о зонно-блоковой структуре литосферы. Ее конкретные формы и иерархия отчетливо выделяются при анализе дистанционных данных и материалов полевых геолого-геофизических съемок. В приповерхностной части и до глубин в первые десятки километров проявлено деление земной коры на относительно слабонарушенные блоки, которые контактируют по широким зонам, отличающимся повышенной дислоцированностью и флюидонасыщенностью. Динамика разломообразования в этих зонах обусловливает пространственно-временные проявления сейсмической и радоновой активности. Как следствие, в основе моделей сейсмичности и других важных в практическом отношении сопутствующих деструкции явлений должны лежать структурные особенности земной коры, а также закономерности их изменений в масштабах реального времени. Экспериментальные данные, позволяющие прогнозировать динамику разломообразования, свидетельствуют, что этот процесс сложен вследствие селективной активизации разрывов в меж- 
блоковых зонах литосферы. В то же время полученные результаты, в т.ч. и данные экспериментов по управлению режимом смещений в разломных фрагментах, позволяют рассчитывать на выявление устойчивых закономерностей в дальнейшем.

Вследствие изложенного выше научные перспективы коллектива сотрудников лаборатории тектонофизики связаны с разработкой комплексных моделей межблоковых зон, в основе которых лежат особенности разломного строения, а содержательную часть составляют обусловленные ими закономерности сейсмической, эманационной и флюидной активности. Такие модели служат современным теоретическим обеспечением создания разнотипных прикладных технологий, направленных на оценку радоноопасности территорий, прогноз сейсмической активности и опасных инженерно-геологических процессов и явлений.

Успех в развитии намеченного научного направления зависит от полноты информации о деструкции литосферы и сопутствующих процессах, протекающих в различных геодинамических обстановках. Большое значение в сборе такой информации, кроме анализа литературных данных, имеют рабочие контакты со специалистами из России и других стран. В связи с этим сотрудники лаборатории тектонофизики прини- мали участие в международных геологических конгрессах, ряде совещаний по рифтовым зонам Земли, геодинамике и деструкции литосферы. В 2009 г. к.г.м.н. О.В. Лунина стала Лауреатом национальной премии Л’ОРЕАЛЬ - ЮНЕСКО для молодЫХ российских женщин-ученых.

Лаборатория тектонофизики известна как организатор всероссийских научных совещаний с международным участием: «Разломообразование в литосфере: тектонофизический анализ» (1991 г.), «Напряженное состояние, деформации и сейсмичность литосферы» (2003 г.), «Разломообразование и сейсмичность литосферы: тектонофизические концепции и следствия» (2009 г.), а также IX Международной школы-семинара «Физические основы прогнозирования разрушения горных пород» (2013 г.). В 2014 г. планируется провести очередное совещание по теме «Разломообразование и сопутствующие процессы в литосфере: тектонофизический анализ», посвященное 35-летию лаборатории тектонофизики и 65-летию Института земной коры СО РАН.

Автор выражает благодарность всем научным сотрудникам лаборатории тектонофизики за материалы, предоставленные для подготовки статьи.

\section{8. ЛИТЕРАТУРА ПО ТЕМЕ ИССЛЕДОВАНИЙ (2009-2013 ГГ.)}

\section{1. МОНОГРАФИИ}

Деструкция земной коры и процессы самоорганизации в областях сильного техногенного воздействия / В.Н. Опарин, А.А. Козырев, В.И. Панин, ... В.В. Ружич и др. Новосибирск: Изд-во СО РАН, 2012. 632 с.

Лунина О.В., Гладков А.С., Неведрова Н.Н. Рифтовые впадины Прибайкалья: тектоническое строение и история развития. Новосибирск: Академическое изд-во «Гео», 2009а. 316 с.

Radon: Properties, applications and health hazards / Eds.: Z. Li and C. Feng. Chapter 1. Seminsky K.Zh., Bobrov A.A. Spatial and temporal variations of soil-radon activity in fault zones of the Pribaikalie (East Siberia, Russia). New York: Nova Sci. Publ. Inc., 2012. P. 1-36.

\section{2. СТАТЬИ В ЗАРУБЕЖНЫХ РЕЦЕНЗИРУЕМЫХ ЖУРНАЛАХ}

Lunina O.V., Nevedrova N.N., Gladkov A.S. Tectonic and geoelectric structure of rift basins in the Baikal region // Comptes rendus geosciences. 2012. V. 344. P. 149-158.

Ma Jin, Sherman S.I., Guo Yanshuang. Identification of meta-instable stress state based on experimental study of evolution of the temperature field during stick-slip instability on $5^{\circ}$ bending fault // Science China. Earth Sciences. 2012. V. 55 . № 6. P. 869-881.

Psakhie S.G., Dobretsov N.L., Shilko E.V., Astafurov S.V., Dimaki A.V., Ruzhich V.V. Model study of the formation of deformation-induced structures of subduction type in block-structured media. Ice cover of Lake Baikal as a model medium // Tectonophysics. 2009. V. 465. P. 204-211.

Psakhie S.G., Shilko E.V., Astafurov S.V., Dimaki A.V., Ruzhich V.V. Model study of influence of internal stresses on deformation and seismic processes in convergent plate boundary zones by the example of Lake Baikal ice cover // Geophysical journal. 2010. V. 32. № 4. P. 134-136.

Seminsky K.Zh., Demberel S. The first estimations of soil-radon activity near faults in Central Mongolia // Radiation measurements. 2013. V. 49. P. 19-34.

Vstovsky G.V., Bornyakov S.A. First experiences of seismodeformation monitoring of Baikal rift zone (by the example of South-Baikal earthquake of August 27, 2008) // Natural Hazards and Earth System Sciences. 2010. V. 10. P. 667-672.

\section{3. СТАТЬИ В РОССИЙСКИХ РЕЦЕНЗИРУЕМЫХ ЖУРНАЛАХ}

Андреев А.В., Лунина О.В. Параметры землетрясений и пространственное распределение косейсмических эффектов 
на юге Сибири и в Монголии // Вопросы инженерной сейсмологии. 2012. Т. 39. № 2. С. 25-62.

Астафуров С.В., Гранин Н.Г., Димаки А.В., Псахье С.Г., Ружич В.В., Шилько Е.В. Изучение взаимосвязи деформационной и сейсмической активности в блочных ледовых массивах. Возможности прогноза «ледовых ударов». Модельные исследования на ледовом покрове озера Байкал // Вестник НГУ. Серия: Математика, механика, информатика. 2013. Т. 13. Вып. 3. С. 3-10.

Бержинский Ю.А., Ордынская А.П., Гладков А.С., Лунина О.В., Бержинская Л.П., Радзиминович Н.А., Радзиминович Я.Б., Имаев В.С., Чипизубов А.В., Смекалин О.П. Опыт применения шкалы ESI-2007 для оценки интенсивности Култукского землетрясения 27.08.2008 г. (Южный Байкал) // Вопросы инженерной сейсмологии. 2009. Т. 36. № 3. С. 5-26.

Борняков С.А. Деформационные предвестники Усть-Баргузинского землетрясения 20 мая 2008 г. // Доклады АН. 2010a. T. 431. № 3. С. 400-402.

Борняков С.А. Экспериментальное исследование закономерностей сейсмической активизации разломов в деструктивных зонах литосферы // Физическая мезомеханика. 2010б. Т. 13. № 4. С. 103-108.

Борняков С.А., Встовский Г.В. Первый опыт сейсмодеформационного мониторинга Байкальской рифтовой зоны (на примере Южно-Байкальского землетрясения 27 августа 2008 г.) // Доклады АН. 2010. Т. 431. № 4. С. 537-541.

Борняков С.А., Семенова Н.В. Диссипативные процессы в зонах разломов (по результатам физического моделирования) // Геология и геофизика. 2011. Т. 52. № 6. С. 862-870.

Бурзунова Ю.П. Углы между сопряженными системами приразломных трещин в идеализированных и природных парагенезисах, формирующихся в различных динамических обстановках // Литосфера. 2011. № 2. С. 94-110.

Востриков В.И., Ружич В.В., Федеряев О.В. Система мониторинга обвалоопасных участков бортов глубоких карьеров // Физико-технические проблемы разработки полезных ископаемых. 2009. № 6. С. 118-127.

Гладков А.С., Лунина О.В. Сейсмиты юга Восточной Сибири: проблемы и перспективы изучения // Геодинамика и тектонофизика. 2010а. Т. 1. № 3. С. 249-272.

Гладков А.А., Лунина О.В., Андреев А.В. Некоторые аспекты разработки информационной системы для интегрирования данных по активной тектонике // Геоинформатика. 2013. № 4. С. 6-14.

Гладков А.С., Маковчук И.В., Лунина О.В., Борняков С.А., Потехина И.А. Трехмерная модель разломно-блоковой структуры участка локализации кимберлитовой трубки Юбилейная (Россия) // Геология рудных месторождений. 2010б. Т. 52. № 3. С. 260-279.

Гладков А.С., Радзиминович Я.Б., Лунина О.В. О связи между очагом исторического землетрясения 25 мая 1887 г. и разломом по долине р. Биликтуйка (юг Сибирской платформы) // Геология и геофизика. 2012. Т. 53. № 12. C. $1735-1743$.

Горбунова Е.А., Шерман С.И. Медленные деформационные волны в литосфере: фиксирование, параметры, геодинамический анализ (Центральная Азия) // Тихоокеанская геология. 2012. Т. 31. № 1. С.18-25.

Гуо Ю.С.Х., Ма Джин, Юн Л., Борняков С.А. Экспериментальное изучение процесса прерывистого скольжения по разломам с изгибом // Геодинамика и тектонофизика. 2011. Т. 2. № 1. С. 35-44.

Добрецов Н.Л., Ружич В.В., Псахье С.Г., Черных Е.Н., Шилько Е.В., Левина Е.А., Пономарева Е.И. О совершенствовании способов прогноза землетрясений средствами физического моделирования в ледовом покрове Байкала // Физическая мезомеханика. 2011. Т. 14. № 4. С. 69-79.

Имаев В.С., Чипизубов А.В., Ружич В.В., Смекалин О.П., Семенов Р.М., Имаева Л.П., Ордынская А.П. Тектоническая природа Култукского землетрясения (на юге оз. Байкал) // Сейсмостойкое строительство. Безопасность сооружений. 2009. № 2. С. 35-39.

Константинов К.М., Гладков А.С. Петромагнитные неоднородности зон обжига пермотриасовых траппов месторождения трубки Комсомольская (Якутская алмазоносная провинция) // Доклады АН. 2009. Т. 427. № 2. С. $245-252$.

Коняев П.А., Боровик А.В. Изучение астроклимата Байкальской астрофизической обсерватории оптическими методами // Оптика атмосферы и океана. 2013. Т. 26. № 12. С. 1-5.

Леви К.Г., Шерман С.И., Саньков В.А. Современная геодинамика Азии: карта, принципы составления, геодинамический анализ // Геотектоника. 2009. № 2. С. 78-93.

Лунина О.В. Формализованная оценка степени активности разломов в плиоцен-четвертичное время (на примере Байкальской рифтовой зоны) // Геология и геофизика. 2010. № 4. С. 525-539.

Лунина О.В., Андреев А.В., Гладков А.С. Локализация эпицентра землетрясения доинструментального периода на основе количественного анализа косейсмических деформаций в рыхлых отложениях // Доклады АН. 2011а. T. 438. № 4. С. 543-549.

Лунина О.В., Андреев А.В., Гладков А.С. По следам Цаганского землетрясения 1862 г. на Байкале: результаты исследования вторичных косейсмических деформаций в рыхлых осадках // Геология и геофизика. 2012а. Т. 53. № 6. С. 775-796.

Лунина О.В. Гладков А.С. Разломно-блоковое строение и напряженное состояние земной коры Гусиноозерской впадины и прилегающей территории (Западное Забайкалье) // Геотектоника. 2009. № 1. С. 78-96.

Лунина О.В., Гладков А.С. Фрактальный анализ пространственно-временных изменений эпицентрального поля землетрясений в разных районах Байкальской рифтовой зоны // Вулканология и сейсмология. 2011. № 5. С. 60-75.

Лунина О.В., Гладков А.С., Гладков А.А. Систематизация активных разломов для оценки сейсмической опасности // Тихоокеанская геология. 2012б. Т. 31. № 1. С. 49-60.

Лунина О.В., Гладков А.А., Капуто Р., Гладков А.С. Разработка реляционной базы данных для сейсмотектонического 
анализа и оценки сейсмической опасности юга Восточной Сибири // Геоинформатика. 2011б. № 2. С. $26-35$.

Лунина О.В., Гладков А.С., Неведрова Н.Н. Тектоническое строение, напряженное состояние и геодинамика рифтовых впадин Прибайкалья // Геотектоника. 2010а. № 3. С. 525-539.

Лунина О.В., Гладков А.С., Орлова О.А. Свидетельства палеосейсмических событий в рифтовых впадинах Прибайкалья и их возрастные привязки // Доклады АН. 2009б. Т. 427. № 1. С. 79-83.

Лунина О.В., Гладков А.С., Шерстянкин П.П. Новая электронная карта активных разломов юга Восточной Сибири // Доклады АН. 2010. Т. 433. № 5. С. 662-667.

Лунина О.В., Неведрова Н.Н., Гладков А.С. Тектонофизические и геоэлектрические исследования рифтовых впадин Прибайкалья // Геофизические исследования. 2010в. Т. 11. № 1. С. 5-14.

Мельников М.Г. О волновом механизме активизации разломов в сейсмических зонах литосферы Монголии // Геодинамика и тектонофизика. 2013. Т. 4. № 1. С. 69-81.

Псахье С.Г., Шилько Е.В., Астафуров С.В., Димаки А.В., Гранин Н.Г., Ружич В.В., Гнатовский Р.Ю. Роль внутренних напряжений в плитных средах как фактора, определяющего деформационную активность на границах раздела. Оценка величины избыточных «тектонических» напряжений // Физическая мезомеханика. 2010. Т. 13 . № 3. C. 98-103.

Рассказов С.В., Шерман С.И., Леви К.Г., Ружич В.В., Кожевников В.М., Саньков В.А. Академик Н.А. Логачев и его научная школа: вклад в изучение кайнозойского континентального рифтогенеза // Геодинамика и тектонофизика. 2010. Т. 1. № 3. Р. 209-224.

Ребецкий Ю.Л., Гончаров М.А., Кузьмин Ю.О., Семинский К.Ж., Шерман С.И. Тектонофизические совещания в СССР и России: информация накануне третьей тектонофизической конференции в ИФЗ РАН: «Тектонофизика и актуальные вопросы наук о Земле» (Москва, 8-12 октября 2012 г.) // Геодинамика и тектонофизика. 2012. Т. 3. № 3. С. 309-314.

Ружич В.В. Очаг землетрясения как объект геологического изучения // Физика Земли. 2009. № 11. С. 1-9.

Ружич В.В., Левина Е.А., Востриков В.И. К проблеме прогноза горных ударов в подземных выработках, пройденных на месторождениях полезных ископаемых // Известия Сибирского отделения секции наук о Земле Российской академии естественных наук. Геология, поиски и разведка рудных месторождений. 2009а. Вып. 35. № 2.

Ружич В.В., Псахье С.Г., Черных Е.Н., Борняков С.А., Гранин Н.Г. Деформации и сейсмические явления в ледяном покрове оз. Байкал // Геология и геофизика. 2009б. № 3. С. 289-299.

Семинский К.Ж. Главные факторы развития впадин и разломов Байкальской рифтовой зоны: тектонофизический анализ // Геотектоника. 2009. № 6. С. 1-17.

Семинский К.Ж., Бобров А.А. Радоновая активность разломов (на примере Западного Прибайкалья и Южного Приангарья) // Геология и геофизика. 2009а. Т. 50. № 8. С. 881-896.

Семинский К.Ж., Бобров А.А. Сравнительная оценка радоновой активности разнотипных и разноранговых разломов Байкальского рифта и юга сибирской платформы // Доклады АН. 2009б. Т. 427. № 4. С. 521-525.

Семинский К.Ж., Дэмбэрэл С., Тугарина М.А., Ганзориг Д., Борняков С.А. Первые оценки объемной активности почвенного радона в разломных зонах Центральной Монголии // Доклады АН. 2012а. Т. 447. № 2. С. 199-203.

Семинский К.Ж., Когут Е.И. Определяющие факторы развития впадин и разломов Байкальской рифтовой зоны: результаты физического эксперимента // Доклады АН. 2009. Т. 424. № 1. С. 76-79.

Семинский К.Ж., Кожевников Н.О., Черемных А.В., Поспеева Е.В., Бобров А.А., Оленченко В.В., Тугарина М.А., Потапов В.В., Бурзунова Ю.П. Межблоковые зоны северо-западного плеча Байкальского рифта: результаты комплексных геолого-геофизических исследований по профилю п. Баяндай - м. Крестовский // Геология и геофизика. 2012б. Т. 53. № 2. С. 250-269.

Семинский К.Ж., Кожевников Н.О., Черемных А.В., Поспеева Е.В., Бобров А.А., Оленченко В.В., Тугарина М.А., Потапов В.В., Зарипов Р.М., Черемных А.С. Межблоковые зоны в земной коре юга Восточной Сибири: тектонофизическая интерпретация геолого-геофизических данных // Геодинамика и тектонофизика. 2013. Т. 4. № 3. С. 203-278.

Семинский К.Ж., Радзиминович Я.Б. Поперечные размеры и латеральная зональность Байкальского сейсмического пояса // Доклады АН. 2011. Т. 438. № 1. С. 114-117.

Семинский К.Ж., Тугарина М.А. Особенности подземной гидросферы западного плеча Байкальского рифта: результаты гидрогеологических исследований вдоль профиля п. Баяндай - м. Крестовский // Доклады АН. 2011а. Т. 439. № 6. С. 775-779.

Семинский К.Ж., Тугарина М.А. Результаты комплексных исследований подземной гидросферы западного плеча Байкальского рифта (на примере участка п. Баяндай - м. Крестовский) // Геодинамика и тектонофизика. $2011 б$. T. 2. № 2. C. 126-144.

Семинский К.Ж., Черемных А.В. Трещинные сети и поля напряжений в кайнозойских осадках Байкальского рифта: новые возможности структурно-парагенетического анализа // Геология и геофизика. 2011. Т. 52. № 3. С. 450-469.

Черемных А.В. Внутренняя структура разломных зон Приольхонья и эволюция напряженного состояния верхней коры Байкальского рифта // Геодинамика и тектонофизика. 2010а. Т. 1. № 3. С. 273-284.

Черемных А.В. Разломно-блоковая структура и напряженное состояние верхней коры восточного побережья озера Байкал (натурные наблюдения и моделирование) // Физика Земли. 2010б. № 5. С. 41-48.

Черемных А.В. Поля напряжений в зоне Приморского сброса (Байкальский рифт) // Литосфера. 2011. № 1. С. 135142.

Черных Е.Н., Ключевский А.В., Ружич В.В. Сравнительное исследование записей катастрофического восточнояпонского землетрясения на скальном грунте и ледовом покрове озера Байкал // Вопросы инженерной сейсмоло- 
гии. 2011. Т. 38. № 4. С. 29-38.

Шерман С.И. А.В. Пейве - основоположник учения о глубинных разломах // Геотектоника. 2009а. № 2. С. $20-36$.

Шерман С.И. Естественные триггерные механизмы нарушения метастабильного состояния разломно-блоковой среды литосферы в реальном времени // Физико-технические проблемы разработки полезных ископаемых. 20096. № 5. С. 33-48.

Шерман С.И. Естественные триггерные механизмы нарушения метастабильного состояния разломно-блоковой среды литосферы в реальном времени // Физико-технические проблемы разработки полезных ископаемых. 2009в. № 5. С. 33-38.

Шерман С.И. Тектонофизическая модель сейсмической зоны: опыт разработки на примере Байкальской рифтовой системы // Физика Земли. 2009г. № 11. С. 8-21.

Шерман С.И. Деформационные волны как триггерный механизм сейсмической активности в сейсмических зонах континентальной литосферы // Геодинамика и тектонофизика. 2013. Т. 4. № 2. С. 83-117.

Шерман С.И., Горбунова Е.А. Вариации и генезис сейсмической активности разломов Центральной Азии в реальном времени // Вулканология и сейсмология. 2011. № 1. С. 63-76.

Шерман С.И., Злогодухова О.Г. Сейсмические пояса и зоны Земли: формализация понятий, положение в литосфере и структурный контроль // Геодинамика и тектонофизика. 2011. Т. 2. № 1. С. 1-34.

Шерман С.И., Лысак С.В., Горбунова Е.А. Тектонофизическая модель Байкальской сейсмической зоны, ее тестирование и возможности среднесрочного прогноза землетрясений // Геология и геофизика. 2012. Т. 53. № 4. С. 508526.

Шерман С.И., Семинский К.Ж. Тектонофизические исследования в Институте земной коры СО РАН: принципиальные достижения и актуальные задачи // Геодинамика и тектонофизика. 2010. Т. 1. № 1. С. 4-23.

Шерман С.И., Сорокин А.П., Сорокина А.Т., Горбунова Е.А., Бормотов В.А. Новые данные об активных разломах и зонах современной деструкции литосферы Приамурья // Доклады АН. 2011. Т. 439. № 5. С. 685-691.

Шилько Е.В., Астафуров С.В., Ружич В.В., Псахье С.Г. О возможности оценки уровня сдвиговых напряжений на границах раздела в блочных средах // Физическая мезомеханика. 2009. Т. 12. № 3. С. 15-22.

Chernykh E.N., Klyuchevskii A.V., Ruzhich V.V. Comparison of nearby earthquake rrecords made on hard rock ground and on ice cover of Lake Baikal // Seismic Instruments. 2013. V. 49. № 3. P. 265-274.

Radziminovich Ya.B., Imaev V.S., Radziminovich N.A., Ruzhich V.V., Smekalin O.P., Chipizubov A.V. The August 27, 2008, $\mathrm{M}_{\mathrm{W}}=6.3$, Kultuk Earthquake effects in the nearepicenter zone: Macroseismic Survey Results // Seismic Instruments. 2010. V. 46. №. 2. P. 107-120.

Seminsky K.Zh. Internal structure of fault zones: spatial and temporal evolution studies on clay models // Geodynamics \& Tectonophysics. 2012. V. 3. № 3. P. 183-194.

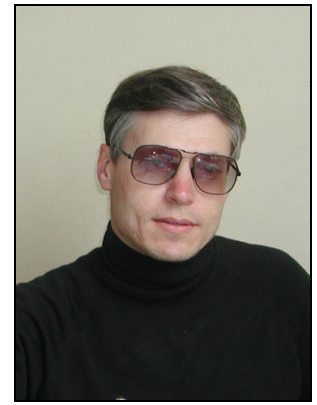

Семинский Константин Жанович, докт. геол.-мин. наук, зав. лабораторией тектонофизики

Институт земной коры СО РАН

664033, Иркутск, ул. Лермонтова, 128, Россия

Тел.: 8(3952)423027; $ه$ e-mail: seminsky@crust.irk.ru

Seminsky, Konstantin Zh., Doctor of Geology and Mineralogy, Head of Laboratory of Tectonophysics Institute of the Earth's Crust, Siberian Branch of RAS

128 Lermontov street, Irkutsk 664033, Russia

Tel.: 8(3952)423027; $\$ e-mail: seminsky@crust.irk.ru 